\title{
Chronic over-nutrition and dysregulation of GSK3 in diseases
}

\author{
Xunxian Liu and Zemin Yao (D)
}

\begin{abstract}
Loss of cellular response to hormonal regulation in maintaining metabolic homeostasis is common in the process of aging. Chronic over-nutrition may render cells insensitive to such a hormonal regulation owing to overstimulation of certain signaling pathways, thus accelerating aging and causing diseases. The glycogen synthase kinase 3 (GSK3) plays a pivotal role in relaying various extracellular and intracellular regulatory signals critical to cell growth, survival, regeneration, or death. The main signaling pathway regulating GSK3 activity through serine-phosphorylation is the phosphoinositide 3-kinase (PI3K)/phosphoinositide-dependent kinase-1 (PDK1)/Akt relay that catalyzes serinephosphorylation and thus inactivation of GSK3. In addition, perilipin 2 (PLIN2) has recently been shown to regulate GSK3 activation through direct association with GSK3. This review summarizes current understanding on environmental and nutritional factors contributing to GSK3 regulation (or dysregulation) through the PI3K/PDK1/Akt/GSK3 axis, and highlights the newly discovered role that PLIN2 plays in regulating GSK3 activity and GSK3 downstream pathways.
\end{abstract}

\section{Background}

Glycogen synthase kinase 3 (GSK3) is a serine/threonine protein kinase [1] and catalyzes phosphorylation of perhaps more than 100 substrates [2]. A unique feature associated with GSK3 regulation is that the enzyme is "constitutively" activated (i.e. always in the "on" stage") in cells [3], probably due to a recently identified phosphorylation of GSK3 catalyzed by protein kinase (PK) Cל [4]. Physiological inhibitors of GSK3 include phosphoinositide 3-kinase (PI3K)/phosphoinositide-dependent kinase-1 (PDK1)/Akt relay [5], as well as the newly identified lipidbinding protein perilipin 2 (PLIN2), also known as adipose differentiation-related protein (ADRP) [6]. In the PI3K/PDK1/Akt relay, Akt is activated by PDK1 [7], and PDK1 in turn is activated by PI3K-generated 3phosphorylated phosphoinositides [8]. In this review, the PI3K/PDK1/Akt axis involved in GSK3 inhibition is abbreviated as PI3K/Akt pathway. Because PI3K activities are modulated by a variety of factors, including hormones, lipid, drugs, food components and food metabolic products through their respective receptors [9], the PI3K/Akt/GSK3 axis represents a major regulatory pathway that relays extracellular and

\footnotetext{
* Correspondence: zyao@uottawa.ca

Department of Biochemistry, Microbiology and Immunology, Ottawa Institute of Systems Biology, University of Ottawa, 451 Smyth Road, Ottawa, ON K1H 8M5, Canada
}

intracellular signals critical to cell growth, survival, regeneration, or death.

It is thus generally believed that negative regulation of GSK3, through PI3K/Akt-mediated phosphorylation, keeps GSK3 activity at "off" or "low" stages [2]. Under disease conditions, either genetic abnormalities or unhealthy environmental factors (such as life style, habits, psychology, and medication) can break cellular homeostasis and lead to increased GSK3 activity and/or unbridled GSK3 activation. Overly activated GSK3 in disease stages, interestingly, can occur when PI3K/Akt is either repressed (resulting from exogenous or endogenous inhibitors or lack of stimuli) or over-stimulated (resulting from high levels of stimuli). High GSK3 activity has been implicated in Bipolar Disorder [9], Parkinson's disease [1], Alzheimer's disease, and Type 2 diabetes (T2D) [10]. Locally low GSK3 activity yet systemically high GSK3 activity may associate with cancer $[5,6,10]$. Moreover, GSK3 can promote inflammation [11] and has been suggested to play a role in aging and age-related macular degeneration [5]. Many of these chronic abnormalities are considered as degeneration diseases. High GSK3 activity perhaps is also linked with several other chronic diseases, such as acquired immune deficiency syndrome (AIDS), cardiovascular diseases (CVD), liver diseases, lung diseases, and renal 
failure, which are associated with age, inflammation, and/or T2D $[5,6]$.

In addition to the PI3K/Akt/GSK3 axis, the GSK3 activity can also be attenuated by PLIN2 via its direct binding to GSK3 [6]. Serine phosphorylation of GSK3 (pSGSK3), catalyzed by Akt, renders GSK3 inactivation [5], whereas tyrosine phosphorylation of GSK3 (pYGSK3) results in an active form of the enzyme. GSK3 can be serine-phosphorylated by a number of kinases, including PKA [12], PKB (Akt) [5], and PKC $\alpha$ [13], even though in most studies only the Akt activity is measured. The increase in GSK3 activity can be achieved through at least three mechanisms, (i) tyrosine-phosphorylation (pYGSK3) [6], (ii) dissociation from PLIN2 [6], and (iii) lowered serine-phosphorylation (pSGSK3) [5]; all of which exert similar impacts on cell growth/survival $[5,6]$. High GSK3 activity is invariably associated with increased cell apoptosis [14-16], causing abnormal cell death as well as cell regeneration [5].

High intracellular lipid levels for different time periods appear to modulate PLIN2 binding to GSK3 and to GSK3 substrates, thus impacting the GSK3 activity and GSK3 downstream pathways, in turn, cell survival/ growth [6]. High and low GSK3 activities in the body may underlie the biological mechanisms due to hyperlipidemia and obesity [6]. Elevated intracellular lipid concentrations mimic the body cells under hyperlipidemia and obesity circumstances [6], and obesity is closely associated with increased risks of chronic diseases, including Alzheimer's disease [17], cancer, CVD, T2D [18], and hyperlipidemia [17].

Loss of cellular response to hormonal regulation in maintaining metabolic homeostasis is common in the process of aging [5]. Chronic over-nutrition creates an environment that overly stimulates certain signaling pathways (e.g. PI3K/Akt), which can render cells insensitive to hormonal stimulation. This "overstimulation-induced insensitivity" phenomenon is commonly present in almost all of the metabolic disorders. This review focuses on overstimulation-induced insensitivity of GSK3, particularly on the signaling pathways that negatively modulate GSK3 activity and on the environmental and nutritional factors contributing to GSK3 regulation through the PI3K/PDK1/Akt/GSK3 axis. Current understandings on the newly discovered role that PLIN2 plays in regulating GSK3 activity and GSK3 downstream pathways are also highlighted. Although changes in the PI3K/Akt activities may also crosstalk to PLIN2mediated GSK3 regulation, there is no such information reported in the literature. Therefore, the two aspects of GSK3 regulation are presented separately in this review. The well-described negative regulation of GSK3 activity by the Wnt signaling pathway is not discussed in this review.

\section{Regulation of GSK3 through phosphorylation/ de-phosphorylation}

Because GSK3 is constitutively activated [3], regulation of GSK3 is achieved mainly through the inhibitory serine-phosphorylation; namely, phosphorylation of serine21 in GSK3 $\alpha$ and phosphorylation of serine-9 in GSK3 $\beta$ in mammals. GSK3 is connected to extracellular environment primarily via PI3K/Akt, and thus maintenance of those kinase activities is essential for GSK3 inhibition. Activation of PI3K is achieved by various types of cell receptor signaling that in succession is modulated by alteration of environmental and/or genetic factors.

Although normal repression of GSK3 activity is controlled by consecutive PI3K/PDK1/Akt activations, overstimulation of receptors, the upstream of PI3K under many disease conditions can cause insensitivity of the PI3K/Akt/GSK3 pathway and result in uninhibited GSK3 activity [5]. For instance, long-term treatment with hormones that are members of the growth hormone family, such as vascular endothelial growth factor (VEGF) can cause GSK3/Akt/PI3K insensitivity and activate GSK3 in cultured cells [5], whereas repeatedly administrating growth hormone, approximately equating to long-term hormone treatment is often associated with adverse effects such as diabetes and glucose intolerance in humans [19], which is attributable to possible high GSK3 activity. Likewise, persistent existence of a stimulus, such as high expression of interleukin 17 receptor C (IL17RC) in eyes and peripheral blood cells in age-related macular degeneration, is also associated with increased GSK3 activity $[5,20]$. Endogenous ligands such as thyroxine [21] and growth hormone can also activate Akt and PI3K/Akt pathway $[22,23]$. Decrease in sensitivity towards such ligands in aged cells $[19,21]$ is probably associated with diminished PI3K/Akt activation, which in turn contributes to uncontrolled GSK3 activity [5].

Therefore, release of GSK3 activity, a hallmark of PI3K/ Akt/GSK3 pathway insensitivity can happen under disease conditions as a consequence of any of the following events: (i) overstimulation of PI3K/Akt, (ii) reduction of using native PI3K/Akt stimuli, and (iii) inhibition of PI3K/Akt.

Animal and cell culture studies combined have suggested that release of GSK3 activity can occur under different stages of PI3K/Akt/GSK3 pathway insensitivity. Based on immunoblot analysis of the phosphorylation status of the kinases, we have postulated that there are four stages (stage 0 through stage 3) of PI3K/Akt/GSK3 insensitivity [5]. Of those, the overstimulation-induced GSK3 insensitivity and activity are developed stage-wise, i.e. GSK3 insensitivity occurs first, which precedes Akt insensitivity and in turn PI3K insensitivity [5]. In stage 1, high GSK3 activity coincides with high PI3K and Akt activities; in stage 2: high GSK3 activity occurs where PI3K activity is high yet Akt activity is unchanged or low; in stage 3, high GSK3 activity 
coexists with low PI3K and Akt activities (Table 1). Thus, the higher the stage is, the more damages of the kinases sensitivity; moreover, the longer stimulus of the same system, the higher stage of the kinases insensitivity [5], which suggests that the highest stage can be reached in any system as long as a stimulation lasts sufficiently long. The overstimulation-induced insensitivity of PI3K/Akt/GSK3 can be pathway specific, as for example, IL17RC overexpression has little impact on the sensitivity of extracellular signal-regulated kinases (ERK) or Wnt signaling [5]. At stage 0 , the kinases do not lose their sensitivity for normal regulation of phosphorylation, despite manifestation of diseases such as insulin resistance [24].

\section{Regulation of GSK3 through PLIN2}

The perilipin (PLIN) family consists of a group of cytoplasmic proteins with sequence homology and characteristic binding to cytosolic lipid droplets [25]. A typical PLIN protein consists of a two-domain structure; the Nterminal lipid-binding domain and the C-terminal $\alpha$ helix bundle, resembling some of the exchangeable apolipoproteins [26, 27]. While some PLIN proteins (e.g. PLIN1 and PLIN2) appear exclusively in association with lipid droplets, other PLIN proteins (e.g. PLIN3 or Tip47) can bind to subcellular organelles in addition to lipid droplets [28]. Mechanisms that regulate the PLIN protein partitioning between lipid droplets and organellar membranes are not defined.

Although it is generally believed that PLIN proteins are important for the metabolism (especially catabolism) of intracellular lipids [29], the exact role that PLIN plays in cellular lipid homeostasis remains largely unclear. Attempts were made to determine PLIN2 function using genetic manipulation approaches, such as antisense oligo [30], gene-knockout [31,32], or siRNA in mice [33] or cultured cell lines [6]. Although data obtained from gene-knockout studies were confounded by the presence of a truncated PLIN2 segment in the mouse model [34], it is apparent that PLIN2 depletion in mice, even though the ablation may not be complete, is associated with amelioration of diet-induced hepatosteatosis, obesity, and adipocyte inflammation [32]. On the other hand, forced overexpression of PLIN2 in macrophages [35], hepatic stellate cells [36], HEK293 cells [37], or skeletal muscle C2C12 cells [33] could result in increased cytosolic lipid droplet content. The increase in cellular lipids, upon PLIN2 expression, cannot be predominantly attributed to increased lipid synthesis; rather, it is likely due to decrease in lipid turnover.

A potential role of PLIN2 overexpression in glucose uptake has been recently demonstrated using transfected mouse fibroblast $\mathrm{L}$ cells and differentiated 3T3-L1 adipocytes [38]. In these cells, a negative correlation between PLIN2 expression and glucose uptake was observed; thus, overexpression of PLIN2 in these cells results in markedly decreased glucose uptake, whereas PLIN2 knock-down is associated with manifold increase in glucose uptake [38]. The exact mechanism whereby PLIN2 expression could attenuate cellular glucose uptake is uncertain. It was assumed that PLIN2 might sequester SNAP27, a protein component of the SNARE complex that is required for the glucose transporter 1 trafficking to and from the plasma membranes [38]. Overexpression of PLIN2 alleviates insulin resistance in skeletal muscle cells [33].

We have recently obtained experimental evidence that PLIN2 is a GSK3-associated protein playing an obligatory role in the Wnt/Frizzled pathway, probably through acting as an intermediate between Dishevelled 2 (Dvl2) and the axin/GSK3 $\beta / \beta$-catenin complex (AG $\beta C$ ) [6]. In 3T3-L1 and HEK293 cells, PLIN2 is required for Wntregulated disruption of axin/GSK3 complexes; upon Wnt- $3 \alpha$ stimulation, the association of Dvl2/PLIN2 is decreased and concomitantly the association between $A G \beta C$ and PLIN2 is increased within $15-30 \mathrm{~min}$ [6]. Importantly, this PLIN2-dependent AG $\beta C$ disassembly appears to be independent of pSGSK3 levels, because its levels are unchanged upon Wnt stimulation [6]. The effect also appears to be specific to PLIN2, because silencing PLIN3 has no effect on Wnt-induced $\beta$-catenin stability [6]. The role played by PLIN2 as a relay between Dvl2 and $A G \beta C$ in the canonical Wnt signaling was further authenticated by experiments in which $G \alpha_{o / q}$ were silenced; silencing $G \alpha_{o}$ and $G \alpha_{q}$ abolished the Wnt-decreased Dvl2/PLIN2 association and Wntincreased GSK3//PLIN2 association [6].

It is known that Wnt stimulation can inhibit GSK3mediated $\beta$-catenin phosphorylation through either

Table 1 Stages of the kinases insensitivity under disease conditions

\begin{tabular}{|c|c|c|c|c|c|c|}
\hline Stage & Model system & PI3K activity & Akt activity & GSK3 activity & Insensitive kinase & Phenotype \\
\hline 0 & Male Sprague Dawley (SD) Rats & High & High & Low & None & $\begin{array}{l}\text { Early insulin } \\
\text { resistance }\end{array}$ \\
\hline 1 & $\begin{array}{l}\text { Human retinal pigment epithelial } \\
\text { cells (HRPE) treated with VEGF }\end{array}$ & High & High & High & GSK3 & Low growth \\
\hline 2 & $\begin{array}{l}\text { Human monocytes overexpressing } \\
\text { IL17RC or treated with VEGF }\end{array}$ & High & $\begin{array}{l}\text { Unchanged } \\
\text { or low }\end{array}$ & High & GSK3, Akt & Low growth \\
\hline 3 & HRPE overexpressing IL17RC & Low & Low & High & GSK3, Akt, PI3K & Low growth \\
\hline
\end{tabular}


disruption or else alteration of the AG $\beta C$ s [39]. However, disassembly of the AGBCs is not associated with changes in GSK3 serine-phosphorylation. For instance, Wnt-induced, PLIN2-dependent AG $\beta C$ disassembly in 3T3-L1 and HEK293 cells, as mentioned above, is unrelated to changes in pSGSK3 levels [5]. It is also known that $\beta$-catenin phosphorylation by the activity of GSK3 coupled to the AGBC is not controlled by the GSK3 serine-phosphorylation mechanism [2].

PLIN2 expression levels also exert an impact on cell growth; forced expression of PLIN2 in 3T3-L1 cells results in accelerated cell growth, which is associated with increased expression of GSK3 substrates including $\beta$ catenin, CCAAT enhancing binding protein $\alpha$ (c/EBP $\alpha)$, c-Myc, and cyclin D1 [6]. Conversely, silencing PLIN2 in the cells leads to a reduced expression of these GSK3 substrates. PLIN2 depletion also results in dropped pSGSK3 levels, indicative of attenuated GSK3 inhibition [6].

Showing that temporary PLIN2 depletion can decrease Wnt signaling including stabilization of $\beta$-catenin, a cotranscription factor, and expression of transcription activators (c/EBP $\alpha$ and c-Myc) and a cell-survival factor (cyclin D1), the above cell culture studies [6] suggest a developmental role of PLIN2, since regulated Wnt-signaling is essential for development [39]. The decreased cell growth/ survival upon PLIN2 depletion is linked with decreased expression of the aforementioned substrates and increased GSK3 activity [6], which are known to induce cell apoptosis [14-16]. These cell culture PLIN2 silencing data apparently are in discord with the PLIN2 knockout mouse data, because homozygotes for a targeted PLIN2 mutation did not display discernible growth retardation [32]. It was found that a truncated PLIN2 protein, representing the Cterminal $80 \%$ of the full-length PLIN2, was expressed in some tissues of the PLIN2 knockout mice [34]. The residual expression of this truncated PLIN2 protein (missing a region encoded by exons 2 and 3 of murine PLIN2) may still support normal mouse development, whereas animal models entirely devoid of PLIN2 may not survive in vertebrates $[6,31]$.

It has been well documented that cellular PLIN2 concentration is positively correlated with intracellular lipid contents [40]. Thus, treatment of cells with fatty acids, such as oleic acid, to stimulate cytosolic lipid droplet formation invariably generates increased cellular PLIN2 concentrations [40]. Remarkably, treatment of cells with oleic acid not only attenuated the Wnt-3 $\alpha$ induced associations between PLIN2 and AG $\beta C$ components, in the face of elevated PLIN2 concentrations, but also inhibited $\beta$-catenin/T-Cell Factor (TCF) signaling [6]. Presumably, PLIN2 in oleic acid-treated cells is sequestered by cytosolic lipid droplets via PLIN2 strong lipid-binding affinity and therefore is unable to participate in mediating Wnt signaling [6]. The mechanism of oleic acid treatment suppressing Wnt-signaling is further confirmed by the treatment causing reduction of Wntinduced AG $\beta$ C/PLIN2 associations, whereas the treatment generates low levels of Dvl2/PLIN2 association similar to that under mere Wnt treatment [6].

Obesity increases the risks of many chronic diseases, including T2D, Alzheimer's disease, cancer, CVD and hyperlipidemia $[17,18]$. Diet-induced obesity and hyperlipidemia are often revealed by increases of both extracellular and intracellular lipid contents in human body [33, 41]. Data obtained from cell culture studies [6] suggest that the effects of intracellular lipid on GSK3 activity are timedependent. Thus, the short-term oleic acid treatment actually significantly stimulates GSK3/PLIN2 association, suggesting that lower GSK3 activity at this stage raises the expression of c-Myc and cyclin D1 as well as cell growth/ survival [6]. These data are consistent with studies showing that the cytosolic lipid droplets enhance TCF activity and carcinogenesis in colorectal cancer stem cells [42]. The short-term oleic acid treatment engenders intensified associations of GSK3/PLIN2 and PLIN2/GSK3 substrates at least in one cell line studied [6]. Thus, the increase in cell growth, upon short-term oleic acid treatment, is likely due to low GSK3 activity and high expression of c-Myc and cyclin D1, a Wnt-like effect mediated by PLIN2 [6]. These studies support the possibility that low GSK3 activity increases the risks of cancer [10].

On the other hand, in long-term oleic acid treatment, GSK3/PLIN2 association is lowered but GSK3 activity is increased. Thus, under this condition, association of GSK3/PLIN2 is inversely related to GSK3 activity that inhibits the expression of GSK3 substrates (e.g. c-Myc, cyclin D1, and insulin receptor substrate 1 (IRS1)) and cell growth/survival [6]. Presumably, dissociation of GSK3/PLIN2 may allow GSK3 to contact its substrates and synergistically to augment GSK3 activity in addition to lipid-induced pYGSK3 activity [6]. In this case, increase in intracellular lipids is functionally equivalent to PLIN2 depletion, bringing in increased degradation and/or phosphorylation of GSK3 substrates.

High levels of GSK3 activity under long-term oleic acid treatment conditions are associated with decreased c-Myc and cyclin D1 expression. Consequently, the cell growth/ survival is reduced [6]. The influence of oleic acid treatment on GSK3 activity suggests a potential regulatory role of PLIN2 during the interplay of intracellular lipid metabolism and cell functionality, which may support a biological mechanism of diseases risks associated with increased hyperlipidemia and obesity. Indeed, high levels of GSK3 activity are detected in Alzheimer's disease and T2D [10], and increased apoptosis has been observed [14-16]. An unrestricted high-fat diet generates increased GSK3 activity in the brain of a mouse model for Alzheimer's disease study [43]. Detection of high levels of 
GSK3 activity in T2D [10] is probably linked with GSK3mediated IRS1 phosphorylation [44] and degradation [45]. In this regard, the discovery that PLIN2 can interact with IRS1 and that PLIN2 expression exerts a major impact on IRS1 expression [6] is of particularly important significance because IRS1 is also a GSK3 substrate. Therefore, under long-term oleic acid treatment conditions, both high GSK3 activity and dissociation of PLIN2/IRS1 are suggested to promote IRS1 degradation [6], which is a contributing factor to T2D.

To sum up, PLIN2 mediates GSK3 activity in shortterm and long-term oleic acid treatment conditions. If the in vitro cell culture data can be extrapolated to in vivo situation such as hyperlipidemia/obesity (since GSK3 and PLIN2 are ubiquitously expressed), both acute and chronic lipid effects may generate over-suppressed and uncontrolled GSK3 activity, potentially causing divergent damages $[5,6,10]$. Although the mode of GSK3 regulation differs between the PI3K/Akt-mediated mechanism (i.e. serine-phosphorylation) and lipid/PLIN2-mediated mechanism (i.e. tyrosine-phosphorylation and PLIN2/GSK3 interaction) [5, 6], the released GSK3 activity exerts similar impacts on cell growth/survival, which is suggested to have important effects on the initiation and progression of chronic diseases [5].

\section{Dietary and pharmacological considerations that influence GSK3 regulation}

The PI3K/Akt pathway relays a vast number of extracellular signals, through their interaction with cell surface receptors (e.g. cytokine receptors, integrin, receptors of tyrosine kinase (RTK), and G-protein coupled receptors (GPCR)), to GSK3. Nutrients and drugs that either activate or antagonize the PI3K/Akt pathway will inevitably exert an impact on GSK3, and as discussed above, often lead to unchecked GSK3 activation, either through PI3K/Akt or else PLIN2.

Nutrients that affect PI3K/Akt pathway include water, proteins, carbohydrates, and fats (Table 2). Hypo-osmotic [46-48] or hyper-osmotic stresses [49-52] associated with disorders in water homeostasis are known to involve the PI3K/Akt signaling. Non-denatured and denatured proteins can activate PI3K/Akt. Branched-chain amino acids presented in cow milk are highly insulinotropic and a potent activator of PI3K/Akt [53-55]. Increased protein intake causes negative calcium balance in the body [56]. Excess dietary proteins produce a great amount of acids, mostly in the forms of sulfates and phosphates [57]. Magnesium sulfate, fucosylated chondroitin sulfate $[58,59]$, and heparan sulfates [60] all play a role in PI3K/Akt pathway activities.

The interplay between dietary glucose and body insulin response has been well elucidated, and the impairment of insulin-triggered PI3K/Akt signaling is the underlying mechanisms for T2D [61]. Under certain conditions, decreased activation of Akt but not PI3K can occur in skeletal muscles of diabetic rats [62], a situation designated as stage 2 of the kinases insensitivity (Table 1). Moreover, while short-term hyperglycemia activates PI3K/ Akt and suppresses GSK3 [62], prolonged hyperglycemia (as in diabetics) can lead to inflammation and apoptosis associated with high GSK3 activity [14-16, 63, 64].

Hyperlipidemia (i.e. high levels of extracellular lipids) and obesity (i.e. high levels of intracellular lipids) can increase GSK3 activity via (i) suppression/overstimulation of the PI3K/Akt pathway and (ii) dissociation of GSK3/ PLIN2. High extracellular lipids, such as fatty acids, can modulate GSK3 activity via the fatty acid receptor (GPCR) [65] and activation of PI3K/Akt [66]. However, extended high fatty acid concentrations induce insulin resistance by decreasing PI3K activation [67], a situation defined as stage 3 of the kinase insensitivity (Table 1). Although pSGSK3 levels do not differ in cells treated without or with oleic acid [6], cells treated with palmitic acid exhibit increased Akt/PI3K/GSK3 insensitivity [68], also showing the condition of stage 3 of the kinase insensitivity (Table 1). Sterol (including androgen) [69], monoacylglycerol [70], diacylglycerol [71] and mediumchain triacylglycerol [72] all exert an effect on PI3K/Akt.

High level of intracellular lipids, as discussed above, exerts an effect on GSK3 via PLIN2; short-term lipid accumulation increases GSK3/PLIN2 association, whereas long-term lipid accumulation decreases GSK3/PLIN2 association [6]. GSK3 in oleic acid treated cells is activated because of an increased level of pYGSK3 and dissociation of GSK3 from PLIN2 [6]. In vivo studies show that unlimited high-fat diet is associated with low PI3K/Akt and high GSK3 activities, stage 3 of the kinase insensitivity (Table 1) in mouse brains [43]. High fat diet-induced GSK3 activity is linked with development of insulin resistance and T2D in obesity-prone mice [73], so that suppression of GSK3 activity betters insulin-induced glucose metabolism in mice fed high-fat diet [74]. Overexpression of PLIN2 can raise insulin sensitivity in skeletal muscle despite high lipid levels [33], which is probably via high PLIN2 expression-gained IRS1 expression regardless of lipid levels [6]. The same event [6] can also happen in vivo where PLIN2 overexpression attenuates insulin insensitivity induced by high-fat diet [33].

In a broader sense, nutrients also include minerals (Table 3), vitamins (Table 4), food supplements such as antioxidants (Table 5), condiments and ingredients in drinks (Table 6). All of these nutrients, taken up as foodstuff, represent the major environmental factor that influences activities of the PI3K/Akt/GSK3 axis. There are two major types of such environmental factors that can unlock the respective inhibitory effects of PLIN2 and PI3K/Akt on GSK3. One is intracellular lipid that sequesters PLIN2 [6], 
Table 2 Water, proteins or fats affect PI3K/Akt and/or GSK3 activities

\begin{tabular}{|c|c|c|c|}
\hline Nutrient & Model system & Observed effects & Ref. (model) \\
\hline \multicolumn{4}{|l|}{ Water } \\
\hline Hypo-osmotic stress & $\begin{array}{l}\text { Human embryonic kidney cells, mouse } \\
\text { Osteoblast, human thyroid cancer cells, } \\
\text { HRPE, human monocytes and human } \\
\text { neuroblastoma. }\end{array}$ & $\begin{array}{l}\text { Hypo-osmotic pressure induces calcium influx that } \\
\text { mediates PI3K and p53 activation, resulting in cell } \\
\text { apoptosis, which involves high GSK3 activity due } \\
\text { to overstimulation. }\end{array}$ & {$[5,15,46-48]$} \\
\hline Hyper-osmotic stress & $\begin{array}{l}\text { Monkey kidney cells, HeLa cells, human or } \\
\text { mouse melanoma cells, HRPE, } \\
\text { human monocytes. }\end{array}$ & $\begin{array}{l}\text { Despite inducing the p21-activated serine-threonine } \\
\text { kinase, requiring PI3K activation, within } 30 \text {-min, } \\
\text { hyper-osmotic stress suppresses melanin production } \\
\text { that also requires PI3K activation, for days of the } \\
\text { treatment, suggesting overstimulation of the } \\
\text { PI3K Akt pathway. }\end{array}$ & {$[5,49-52]$} \\
\hline \multicolumn{4}{|l|}{ Proteins } \\
\hline Non-denatured protein & Male SD rats, human embryonic kidney cells. & $\begin{array}{l}\text { Branched-chain amino acids in cow milk are highly } \\
\text { insulinotropic and a potent activator of PI3K } A \text { Akt. }\end{array}$ & {$[53,54]$} \\
\hline Denatured proteins & Rat muscle cells. & Increase PI3K. & [55] \\
\hline Excess protein & $\begin{array}{l}\text { Adult women, rats with intestinal } \\
\text { ischemia-reperfusion injury, T2D mice. }\end{array}$ & $\begin{array}{l}\text { Raise calcium excretion; protein-generated } \\
\text { sulfates activate PI3K/Akt via their receptors. }\end{array}$ & {$[56,58,59]$} \\
\hline \multicolumn{4}{|l|}{ Carbohydrates } \\
\hline Glucose & $\begin{array}{l}\text { Humans with diabetes, rat extensor digitorum } \\
\text { longus muscle, mouse cardiac fibroblasts. }\end{array}$ & $\begin{array}{l}\text { Cause insulin response; insulin resistance and } \\
\text { stage } 2 \text { of the kinase insensitivity (Table 1); } \\
\text { modulate PI3KAkt/GSK3 activities; add } \\
\text { inflammation and apoptosis. }\end{array}$ & {$[61-63]$} \\
\hline Fructose & SD rats with diabetes, mouse hepatocytes. & $\begin{array}{l}\text { Increase NF-KB activity which associates with } \\
\text { GSK3 activity. }\end{array}$ & {$[96,97]$} \\
\hline D-galactose & Mice, human neuroblastoma cells. & $\begin{array}{l}\text { Activate caspase- } 3 \text {, which associates with } \\
\text { GSK3/p53 binding. }\end{array}$ & {$[15,98]$} \\
\hline Polysaccharides & $\begin{array}{l}\text { Rats with diabetes, cancer patients, C57BL/6 } \\
\text { mice }[68,99] \text {, human hepatocellular carcinoma, } \\
\text { human melanoma cells, human osteosarcoma, } \\
\text { human gastric carcinoma cells, Balb/c mice, } \\
\text { T2D rats, human hepatocellular carcinoma cells, } \\
\text { KKAy mice. }\end{array}$ & Modulate PI3K/Akt and/or GSK3 activities. & {$[68,99-107]$} \\
\hline \multicolumn{4}{|l|}{ Fats } \\
\hline Intracellular lipid & $\begin{array}{l}\text { Human embryonic kidney cells, human } \\
\text { monocytes, mouse embryonic fibroblasts. }\end{array}$ & $\begin{array}{l}\text { Modulate GSK3/PLIN2 association, GSK3 activity, } \\
\text { expression of GSK3 substrates and cell growth/survival, } \\
\text { and increase pYGSK3 levels (long-term). }\end{array}$ & [6] \\
\hline $\begin{array}{l}\text { Extracellular lipid } \\
\text { including palmitic } \\
\text { acid }\end{array}$ & $\begin{array}{l}\text { Human hepatocellular carcinoma cells, } \\
\text { normal men. }\end{array}$ & $\begin{array}{l}\text { Generate insulin resistance and stage } 3 \text { of the kinase } \\
\text { insensitivity (Table 1) and decrease insulin-induced } \\
\text { PI3K activity. }\end{array}$ & {$[67,68]$} \\
\hline $\begin{array}{l}\text { Sterol including } \\
\text { androgen }\end{array}$ & Human prostate cancer epithelial cells. & Increase Akt activity. & [69] \\
\hline Monoacylglycerol & Mouse neural crest cells. & Activate PI3K. & [70] \\
\hline $\begin{array}{l}\text { Diacylglycerol and } \\
\text { medium-chain } \\
\text { triacyglycerol }\end{array}$ & $\begin{array}{l}\text { Human breast cancer cells, human brain } \\
\text { glioblastoma cells, human alveolar basal } \\
\text { epithelial cells, livers of malnourished } \\
\text { Wistar rats. }\end{array}$ & Activate Akt. & {$[71,72]$} \\
\hline High-fat diet & $\begin{array}{l}\text { C57BL } 16 \text { mice, Tg2576 mice, diabetes- and } \\
\text { obesity-prone C57BL/6 J mice, C57BL/6 } \\
\text { J mice. }\end{array}$ & $\begin{array}{l}\text { Induce insulin insensitivity which can be improved } \\
\text { by overexpression of PLIN2, increase glucose } \\
\text { intolerance and insulin resistance, and decrease } \\
\text { PI3K/Akt activities and raise GSK3 activity, stage } 3 \\
\text { of the kinase sensitivity (Table 1), whereas glucose } \\
\text { metabolism can be ameliorated if GSK3 activity } \\
\text { is inhibited. }\end{array}$ & {$[33,43,73,74]$} \\
\hline High lipid levels & Mouse myoblast cells. & $\begin{array}{l}\text { Overexpression of PLIN2 betters insulin sensitivity } \\
\text { reduced by fatty acids. }\end{array}$ & [33] \\
\hline
\end{tabular}

${ }^{a}$ KKAy mice: The KK-Ay mouse is a T2D model that exhibits marked obesity, glucose intolerance, severe insulin resistance, dyslipidemia, and hypertension 
Table 3 Minerals alter PI3K/Akt and/or GSK3 activities

\begin{tabular}{|c|c|c|c|}
\hline Minerals & Model system & Observed effects & Ref. \\
\hline \multicolumn{4}{|l|}{ High levels in the body } \\
\hline Sodium, chloride, potassium & $\begin{array}{l}\text { Monkey kidney cells, HeLa cells, human } \\
\text { or mouse melanoma, mouse renal distal } \\
\text { convoluted tubule cells, }{ }^{a} \text { Wnk } 4^{+/+} \text {and } \\
\text { Wnk4 }{ }^{\mathrm{D} 561 \mathrm{~A} /+} \text { mice, male SD rats. }\end{array}$ & $\begin{array}{l}\text { High salt foods (mainly NaCl) cause potential } \\
\text { hyperosmotic stress, which modulates } \\
\text { PI3KAkt/GSK3 activities; increase or decrease } \\
\text { phosphorylation of NaCl transporter, regulated } \\
\text { via insulin/PI3K pathway by low salt diet or } \\
\text { high salt diet; high salt food causes early } \\
\text { insulin resistance, stage } 0 \text { of the kinase } \\
\text { insensitivity (Table 1). }\end{array}$ & {$[24,49-52,108,109]$} \\
\hline Calcium & $\begin{array}{l}\text { Mouse osteoblast, human thyroid } \\
\text { cancer cells, mouse neural crest cells. }\end{array}$ & $\begin{array}{l}\text { Exert effects on PI3K/Akt and/or GSK3 } \\
\text { pathway. }\end{array}$ & {$[47,48,110]$} \\
\hline Manganese sulfate & Mouse macrophages. & Anti-inflammation via PI3K/Akt. & [111] \\
\hline Magnesium sulfate & $\begin{array}{l}\text { Rats with intestinal ischemia-reperfusion } \\
\text { injury. }\end{array}$ & Protect injury via PI3K/Akt. & [58] \\
\hline $\begin{array}{l}\text { Fucosylated chondroitin } \\
\text { sulfate }\end{array}$ & T2D mice. & $\begin{array}{l}\text { Improve insulin sensitivity via activation } \\
\text { of PI3K/Akt. }\end{array}$ & [59] \\
\hline Heparan sulfate & $\begin{array}{l}\text { Human normal astrocytes, and malignant } \\
\text { gliomas, human breast cancer cells, } \\
\text { human umbilical vein endothelial cells, } \\
\text { wild type and Syndecan-1-/- mice } \\
\text { infected by influenza. }\end{array}$ & $\begin{array}{l}\text { Increase/Reduce PI3K/Akt/ERK signaling, } \\
\text { carcinogenesis/anti-cancer and } \\
\text { anti-inflammation. }\end{array}$ & {$[112-115]$} \\
\hline Magnesium & Brains of Wistar rats, patients with diabetes. & $\begin{array}{l}\text { Required for GSK3 activation; EDTA Chelation } \\
\text { Therapy decreases CVD events in patients } \\
\text { with diabetes. }\end{array}$ & {$[116,117]$} \\
\hline $\begin{array}{l}\text { Trace levels in the body } \\
\text { Iron }\end{array}$ & Wistar rats, mouse hepatocytes. & $\begin{array}{l}\text { Induce injury regulates PI3K/Akt/GSK3 } \beta \\
\text { pathway, whereas aged rats have less } \\
\text { sensitivity of the regulation; iron oxide } \\
\text { nanoparticles-mediated cytotoxicity } \\
\text { related to PI3K/Akt pathway. }\end{array}$ & {$[118,119]$} \\
\hline Zinc or copper & $\begin{array}{l}\text { Mouse myogenic cells, monkey kidney } \\
\text { cells, mouse embryonic fibroblast, human } \\
\text { hepatoma cells, human neuroblastoma } \\
\text { cells, human prostate epithelial cells. }\end{array}$ & $\begin{array}{l}\text { Stimulates PI3K/Akt signaling, leading to } \\
\text { inhibition of GSK3 } \beta \text {; zinc deficiency adds } \\
\text { Akt signaling. }\end{array}$ & {$[120-124]$} \\
\hline lodine & SD rats. & $\begin{array}{l}\text { Required for synthesis of thyroid hormones } \\
\text { that activates Akt. }\end{array}$ & [22] \\
\hline Manganese & $\begin{array}{l}\text { Mouse microglial cells, human lung } \\
\text { epithelial cells. }\end{array}$ & $\begin{array}{l}\text { Induce inducible nitric oxide synthase } \\
\text { expression via activation of both MAP } \\
\text { kinase and PI3K/Akt pathways; increase } \\
\text { the expression of prostaglandin-endoperoxide } \\
\text { synthase } 2 \text { (COX-2) via p38 and PI3K/Akt. }\end{array}$ & {$[125,126]$} \\
\hline Zinc and manganese & $\begin{array}{l}\text { South Hampshire and Merino } \\
\text { CLN6 sheep. }\end{array}$ & $\begin{array}{l}\text { Increased in the model with reduced } \\
\text { expression of ceroid-lipofuscinosis } \\
\text { neuronal protein } 6 \text {, accompanying with } \\
\text { activation of Akt/GSK3 signaling } \\
\text { (stage } 1 \text { of the kinase insensitivity } \\
\text { (Table I)), and neurodegeneration. }\end{array}$ & [127] \\
\hline Selenium & Human prostate cancer cells. & Reduce the activities of PI3K/Akt. & [128] \\
\hline Aluminum fluoride & Mouse adipose cells. & Induce G-protein-linked PI3K signaling. & [129] \\
\hline Fluorine & SD rats. & $\begin{array}{l}\text { Accumulation of it relates to increase of } \\
\text { PI3K/Akt and p38 and tissue in bone tissue } \\
\text { of fluorosis rats. }\end{array}$ & [130] \\
\hline Chromium & Mouse myoblast cells. & $\begin{array}{l}\text { Increase expression glucose transporter } \\
\text { and insulin receptor, resulting in enhanced } \\
\text { glucose uptake. }\end{array}$ & [131] \\
\hline
\end{tabular}

${ }^{\mathrm{a}} W N K$ with-no-lysine kinase, ${ }^{\mathrm{b}} \mathrm{CLN}$ ceroid-lipofuscinosis neuronal protein 
Table 4 Vitamins change PI3K/Akt and/or GSK3 activities

\begin{tabular}{|c|c|c|c|}
\hline Vitamins & Model system & Observed effects & Ref. \\
\hline Vitamin A & $\begin{array}{l}\text { Mouse embryonic stem cells, } \\
\text { human neuroblastoma cells, } \\
\text { human bronchial epithelium. }\end{array}$ & $\begin{array}{l}\text { PI3K via IGF-1 receptor/IRS1; suppress cyclin D1 } \\
\text { protein expression via GSK3, stage } \geq 1 \text { of the } \\
\text { kinase insensitivity (Table 1). }\end{array}$ & [79-81] \\
\hline Vitamin B1 analog & $\begin{array}{l}\text { Mice with diabetes, mouse } \\
\text { cadiomyocytes, human } \\
\text { embryonic kidney cells, } \\
{ }^{b} \text { APP/PS1 mice. }\end{array}$ & $\begin{array}{l}\text { Activate Akt, preventing diabetes-induced } \\
\text { diastolic dysfunction and heart failure; } \\
\text { avert high glucose-induced } \beta \text {-amyloid } \\
\text { related to GSK3 activity; inhibit GSK3 } \\
\text { activity to subdue cognitive damages } \\
\text { and beta-amyloid accumulation. }\end{array}$ & [132-134] \\
\hline $\begin{array}{l}\text { Vitamin B3 (Niacin) and } \\
\text { vitamin B6 (pyridoxine) }\end{array}$ & $\begin{array}{l}\text { Human epidermoid carcinoma } \\
\text { cells, Chinese hamster ovary } \\
\text { cells, }{ }^{+} \mathrm{Hca}_{2}^{+/-} \text {mice, human platelets. }\end{array}$ & Augment PI3K/Akt activities. & {$[135,136]$} \\
\hline Vitamin B8 (inositol) & Smokers. & Suppress Akt and ERK. & [137] \\
\hline Vitamin B9 (folic acid) & Mouse neural stem cells. & $\begin{array}{l}\text { Stimulate cell growth by modification of } \\
\text { epigenetics of PI3K/Akt/CAMP response } \\
\text { element-binding protein pathway. }\end{array}$ & [138] \\
\hline $\begin{array}{l}\text { Vitamin B10 } \\
\text { (para- aminobenzoic acid) }\end{array}$ & Zebrafish embryos. & $\begin{array}{l}\text { Raise pSGSK3 } \beta \text { reduced by valproic acid, } \\
\text { an anti-epilepic drug). }\end{array}$ & [139] \\
\hline Vitamin B11 (salicylic acid) & $\begin{array}{l}\text { Human umbilical vein endothelial } \\
\text { cells and human foreskin fibroblasts, } \\
\text { murine myoblasts, Humans with } \\
\text { inflammation. }\end{array}$ & $\begin{array}{l}\text { Inhibit COX-2 gene transcription, resulting } \\
\text { in anti-inflammatory effects. }\end{array}$ & [140-142] \\
\hline Vitamin B13 (orotic acid) & $\begin{array}{l}\text { Human umbilical vein endothelial } \\
\text { cells, SD rats. }\end{array}$ & $\begin{array}{l}\text { Patients with orotic acid metabolic disorders } \\
\text { may reduce insulin response and PI3KJAkt } \\
\text { signaling, generating insulin resistance. }\end{array}$ & [143] \\
\hline Vitamin B14 & Human bone marrows. & Increase cell growth and haemopoiesis. & [144] \\
\hline Vitamin B17 (amygdalin) & Human bladder cancer cells. & Inhibit cell growth via activated Akt-related pathways. & {$[145]$} \\
\hline Pyrroloquinoline quinine & $\begin{array}{l}\text { Rat cardiomyocytes, hippocampal } \\
\text { neurons and brain cortex from } \\
\text { SD rats. }\end{array}$ & $\begin{array}{l}\text { Possibly naturally existing in vitamin B complexes } \\
\text { can activate PI3K/Akt and reduce cell apoptosis or } \\
\text { inhibits GSK3 } 3 \text { activity in nervous tissues of } \\
\text { glutamate-injected animals. }\end{array}$ & [146-148] \\
\hline Vitamin $C$ or vitamin $E$ & Human colon cancer cells. & $\begin{array}{l}\text { Inhibit casein kinase } 2 \text { (CKII) downregulation-mediated } \\
\text { aging in cells, whereas suppression of CKII raises } \\
\text { PI3K/Akt activities. }\end{array}$ & [149] \\
\hline Vitamin C & Human breast cancer cells. & $\begin{array}{l}\text { Enhance a synthetic anti-cancer drug, } \\
\text { mitoxantrone-induced cytotoxicity. }\end{array}$ & [150] \\
\hline \multirow[t]{5}{*}{ Vitamin D } & & $\begin{array}{l}\text { Vitamin D receptor mediates PI3K/Akt activation; } \\
\text { vitamin D reduces caspase activities for cell } \\
\text { apoptosis via vitamin D receptor/PI3K/Akt pathway. }\end{array}$ & {$[151,152]$} \\
\hline & $\begin{array}{l}\text { Human myeloid leukaemic cells, } \\
\text { rat osteoblasts. }\end{array}$ & $\begin{array}{l}\text { Vitamin D deficiency induces hyperinsulinemia } \\
\text { and insulin resistance in obese mice. }\end{array}$ & [153] \\
\hline & C57BL/6J mice. & Enhance effects of PI3K inhibitors on cell growth. & {$[154]$} \\
\hline & Human prostate cancer cells. & $\begin{array}{l}\text { Induce the tolerance or immunosuppression } \\
\text { through the PI3KAAkt pathway. }\end{array}$ & {$[155,156]$} \\
\hline & $\begin{array}{l}\text { Human monocyte-derived } \\
\text { tolerogenic dendritic cells, } \\
\text { human CD3+ T cells. }\end{array}$ & $\begin{array}{l}\text { Activate MAP kinase and/or PI3K/Akt for } \\
\text { protecting cell death. }\end{array}$ & \\
\hline \multirow[t]{3}{*}{ Vitamin $\mathrm{E}$} & $\begin{array}{l}\text { Cultured mouse cortical } \\
\text { neurons, human } \\
\text { neuroblastoma. }\end{array}$ & & {$[157,158]$} \\
\hline & $\begin{array}{l}\text { Human breast cancer cells, } \\
\text { human prostate cancer cells. }\end{array}$ & $\begin{array}{l}\text { Tocotrienols (natural forms of vitamin E) or tocopherol } \\
\text { (the saturated form of vitamin E)-associated protein } \\
\text { can suppress cancer growth via inhibition of PI3K. }\end{array}$ & {$[75,76]$} \\
\hline & $\begin{array}{l}\text { Mouse neoplastic mammary } \\
\text { epithelial cells. }\end{array}$ & $\begin{array}{l}\text { Gamma-tocotrienol can block human epidermal } \\
\text { growth factor receptor 3-dependent PI3K/Akt } \\
\text { mitogenic signaling. }\end{array}$ & [77] \\
\hline
\end{tabular}


Table 4 avitamins change PI3K/Akt and/or GSK3 activities (Continued)

\begin{tabular}{|c|c|c|c|}
\hline Vitamin J (catechol) & Mouse microglial cells. & $\begin{array}{l}\text { Iridoid and catechol (vitamin J) derivatives of natural } \\
\text { products, have anti-inflammatory activities via } \\
\text { inhibition of the PI3K Akt and p38 pathways. }\end{array}$ & [159] \\
\hline Vitamin $\mathrm{K}$ & Apoptotic cells. & $\begin{array}{l}\text { Protein Gas } 6 \text { and S are vitamin K dependent proteins } \\
\text { and ligands of RTK that can regulate PI3K/Akt pathway. }\end{array}$ & [160] \\
\hline Vitamin $\mathrm{P}$ & Mouse primary neurons. & $\begin{array}{l}\text { Increase PI3K Akt activities and the survival of } \\
\text { motoneurons via tropomyosin-receptor kinase B. }\end{array}$ & [161] \\
\hline Vitamin $U$ & Mice, rats. & $\begin{array}{l}\text { Vitamin U (methylmethioninesulfonium chloride) } \\
\text { reduces capillaries' permeability of animal skin; } \\
\text { protecting gastric mucosa from lesion caused } \\
\text { by aspirin, an acetylated form of salicylic acid } \\
\text { (vitamin B11) with anti-inflammatory effects. }\end{array}$ & [162] \\
\hline
\end{tabular}

${ }^{\mathrm{a} V i t a m i n s: ~ n o t ~ a l l ~ t h e ~ v i t a m i n s ~ a r e ~ w i d e l y ~ a c c e p t e d ~ a s ~ v i t a m i n s, ~}{ }^{\mathrm{b}}$ APP/PS1 amyloid precursor protein/presenilin-1, ${ }^{\mathrm{C}} \mathrm{Hca} 2$ niacin receptor 1

which may provide a mechanism for the etiology of diseases such as Alzheimer's disease, CVD and T2D that are often associated with obesity. The other is via PI3K/Akt inhibition or overstimulation. High doses of certain vitamins can suppress PI3K/Akt activities [75-77], playing similar roles to that of LY compounds (PI3K inhibitors) [78], which can be defined as over-inhibition events (Fig. 1) since those reagents generate severe physiological effects via suppression of PI3K [75-77], or over-stimulate the pathway [79-81], leading to augmented GSK3 activity with increased risks of mortality [82]. Dampening a food ingredient-induced PI3K/Akt activation [63] or maintaining a hormone-caused unregulated GSK3 activity in regulated ranges [83], antioxidants can buffer the effects (overstimulation) generated by the abnormal factors on the pathway.

Although GSK3 activity has not been uniformly measured in the above cited literatures, given that PI3K/Akt are the major regulators of GSK3 and that those studies present GSK3-associated phenotypes such as inflammation and apoptosis, it is not out of realm to speculate that the diet ingredients that modulate PI3K/Akt would have an impact on GSK3 activity as well. It is noteworthy that studies using the same ingredients sometime yield inconsistent or contradictory results, which could be due to differences in experimental conditions (e.g. dose or duration of the treatment and model systems chosen) that could impact the activation/inactivation of GSK3. Because unconstrained GSK3 activity can be associated with different stages of the kinases' insensitivity (Table 1) or activated GSK3 can be caused by suppression of PI3K/ Akt, it is therefore recommended all three kinases' activities in the PI3K/Akt/GSK3 axis be determined in future studies of disease development. Measurements of mass and phosphorylation status of GSK3, GSK3-related kinases, and GSK3 substrates [4] in peripheral blood mononuclear cells (PBMC) may help diagnosis of subhealth patients $[20,84]$. These measurements may also help selection of control groups in clinical studies and assessment of efficacy of treatment of diseases (e.g. HIV), because activities of GSK3-related kinases are altered by
HIV infection [85-88]. Moreover, these measurements may help establishment of a relationship between GSK3 activity and various chronic and age-related disorders, including insomnia, chronic inflammation (e.g. that causes neuropathy damage) $[89,90]$, as well as pre-diseases/diseases signals (e.g. liver palms, obesity, abnormal face wrinkles, optic redness), among others. Thus, these measurements may supplement blood and urine tests in the surveillance of health conditions among peoples who carry genetic risks of diseases.

\section{Conclusions}

Nature has seemingly selected GSK3 as a gatekeeper of life span. GSK3 3 knockout mice are systemic in apoptosis and die in utero, whereas GSK3 overexpression in mice also results apoptosis [91]. The question concerns whether abnormal GSK3 activity per se limits life span or GSK3 activity represents "the shortest side slab" in the "life span bucket" remains to be addressed experimentally, if possible. Regardless, GSK3 perhaps plays a major role in longevity [92] and in mortality incurred by infections or injury-caused inflammation. There appears to be an "uncertainty principle" governing the relationship between environmental factors and chronic diseases. Acute adverse environmental factors may not necessarily lead to diseases stages and rather create a sub-health condition. Thus, the relationship between cause and effect is not always clear. This uncertainty is also influenced by individual variations. Despite the complexity of cellular signaling pathways and their intrinsic cross talks, the one thing that seems certain is the convergence of high GSK3 activity under all adverse conditions. In this regard, GSK3 activity is inhibited by a short-term stimulus but released by a long-term one (e.g. under oleic acid treatment conditions), and only the increased GSK3 activity is consistent with the observation of metabolic disorders.

The presence of the dual mechanism (i.e. PI3K/Akt-mediated phosphorylation and lipid-mediated GSK3/PLIN2 interaction) for GSK3 regulation provides a link between energy homeostasis and cellular functionality. Whether or 
Table 5 Antioxidants influence PI3K/Akt and/or activities

\begin{tabular}{|c|c|c|c|}
\hline Antioxidants & Model system & Observed effects & Ref. \\
\hline Anthocyanidins & $\begin{array}{l}\text { Hypercholesterolaemic patients, human } \\
\text { stomach cancer cells, human breast } \\
\text { cancer cells, human hepato-carcinoma cells. }\end{array}$ & $\begin{array}{l}\text { Suppress PI3K Akt signaling pathway via } \\
\text { epidermal growth factor receptor pathway, } \\
\text { or levels of pSGSK3 } \beta \text { and } \beta \text {-catenin in a } \\
\text { tumor xenograft model. }\end{array}$ & {$[163-166]$} \\
\hline Mulberry anthocyanidin & Human liver cancer cells. & Activate PI3K/Akt. & {$[167]$} \\
\hline \multirow[t]{2}{*}{ Berberine } & Human melanoma cells, SD rats. & Inhibit PI3K/Akt and/or GSK3 $\beta$ activities. & {$[52,168]$} \\
\hline & $\begin{array}{l}\text { Murine neural crest cells, murine primary } \\
\text { neurons, mice with cerebral and } \\
\text { reperfusion, human chondrosarcoma cells. }\end{array}$ & $\begin{array}{l}\text { Increase PI3K/Akt activities and cell } \\
\text { growth/survival in other studies. }\end{array}$ & {$[169,170]$} \\
\hline \multirow[t]{2}{*}{ Curcumin } & $\begin{array}{l}\text { Human Burkitts' lymphoma, human } \\
\text { esophageal cancer cells, human } \\
\text { renal cancer cells. }\end{array}$ & $\begin{array}{l}\text { Enhance radiation- or PI3K/Akt inhibitors- } \\
\text { induced or directly induce apoptosis by } \\
\text { suppression of PI3K/Akt signaling pathway. }\end{array}$ & [171-173] \\
\hline & $\begin{array}{l}\text { Rat cardiomyocytes, human prostate cancer } \\
\text { cells, Balb/c mice. }\end{array}$ & $\begin{array}{l}\text { Protect cells from apoptosis induced by a } \\
\text { high glucose level via upregulation of } \\
\text { Akt/GSK3 } \beta \text { serine/threonine phosphorylation } \\
\text { levels via protein phosphatase-dependent } \\
\text { mechanism or inhibits GSK3 } \beta \text { activity } \\
\text { in vitro or in vivo. }\end{array}$ & {$[174-176]$} \\
\hline Ergosterol & $\begin{array}{l}\text { Streptozotocin-induced diabetes in mice, } \\
\text { human cancer cells. }\end{array}$ & $\begin{array}{l}\text { Restore PI3K/Akt signaling damaged in } \\
\text { diabetic mice; ergosterol-related compounds } \\
\text { induce cell apoptosis depending on a } \\
\text { protein-promoted Akt activation. }\end{array}$ & {$[177,178]$} \\
\hline Garlicin & Human cellosaurus cells & Suppress PI3K/Akt pathway. & {$[179]$} \\
\hline Garlic & Fructose-fed diabetic SD rats & Activate PI3K/Akt in Diabetes rats. & [96] \\
\hline \multirow[t]{2}{*}{ Luteolin } & $\begin{array}{l}\text { Human epidermoid carcinoma cells and their } \\
\text { murine cells xenograft model, human umbilical } \\
\text { vein endothelial cells, human prostate cancer } \\
\text { cells, human colon cancer cells, human } \\
\text { glioblastoma cells. }\end{array}$ & $\begin{array}{l}\text { Inhibit VEGF-increased PI3K/Akt activities } \\
\text { or IGF-1-increased the phosphorylation } \\
\text { levels of PI3K/Akt/GSK3 or down-regulate } \\
\text { PI3K/Akt pathway. }\end{array}$ & [180-183] \\
\hline & $\begin{array}{l}\text { Cardiomyocyte in rats with ischemia/reperfusion, } \\
\text { murine neural crest cells. }\end{array}$ & $\begin{array}{l}\text { Decrease apoptosis via PI3KJAkt pathway } \\
\text { in a rat model or persistently activate Akt in cells. }\end{array}$ & {$[184,185]$} \\
\hline \multirow[t]{2}{*}{ Lycopene } & Prostate epithelial cells. & $\begin{array}{l}\text { Inhibit IGF-1-induced Akt/GSK3 serine/threonine } \\
\text { phosphorylation levels. }\end{array}$ & [83] \\
\hline & Patients, human prostate cells. & $\begin{array}{l}\text { Its effects on PI3KAAkt pathway are inhibitory } \\
\text { in prostate cancer. }\end{array}$ & {$[186]$} \\
\hline Phytoestrogens & $\begin{array}{l}\text { Human embryonic kidney cells, mouse } \\
\text { preosteoblastic cells. }\end{array}$ & $\begin{array}{l}\text { Increase phosphorylation levels of Akt and } \\
\text { GSK3 } \beta \text { as well as the Wnt/ } \beta \text {-catenin signaling. }\end{array}$ & [187] \\
\hline Isoflavones & Human cancer cells & Inhibit PI3KJAkt signaling in cancer cells. & [188] \\
\hline Soy isoflavone & SD rats with myocardial ischemia/reperfusion. & $\begin{array}{l}\text { Gain PI3K/Akt pathway activities in } \\
\text { ovariectomized rats. }\end{array}$ & [189] \\
\hline Daidzein or genistein & Nude mice with various tumors & $\begin{array}{l}\text { Up-regulate or down-regulate GSK3 gene/protein } \\
\text { expression, and both belong to isoflavones. }\end{array}$ & [190] \\
\hline Psoralidin & Human lung fibroblasts, mice. & $\begin{array}{l}\text { A coumestan derivative suppresses } \\
\text { pro-inflammatory cytokines and } \\
\text { regulates PI3K/Akt pathway. }\end{array}$ & [191] \\
\hline \multirow[t]{2}{*}{ Resveratrol } & Mouse cardiac fibroblasts, human glioma cells. & $\begin{array}{l}\text { Inhibit high glucose-induced PI3K/Akt } \\
\text { pathway and inflammation or reduces } \\
\text { PI3K/Akt activities. }\end{array}$ & {$[63,192]$} \\
\hline & Neural crest cells, APP/PS1 mice. & $\begin{array}{l}\text { Protect cells from apoptosis induced by high } \\
\text { glucose via activation of PI3K/Akt pathways } \\
\text { and increase in vivo pSGSK3 } 3 \text { levels. }\end{array}$ & {$[193,194]$} \\
\hline $\begin{array}{l}\text { Lignan including } \\
\text { honokiol and } \\
\text { sauchinone }\end{array}$ & $\begin{array}{l}\text { Human prostate cancer cells, human myeloid } \\
\text { leukaemic cells, mouse microphage, mouse } \\
\text { lymphoblast, splenic lymphocytes, human } \\
\text { glioma, breast and prostate cancer cells, } \\
\text { human hepatocytes, WT and }{ }^{2} \text { Nrf2 KO C57/BL6 mice. }\end{array}$ & $\begin{array}{l}\text { Inhibits Akt signaling and generate } \\
\text { anti-inflammatory effect via inhibition } \\
\text { of PI3KAkt pathway or mediate suppression } \\
\text { of PI3K; however sauchinone, augments } \\
\text { in vivo pSGSK3 levels. }\end{array}$ & [195-198] \\
\hline
\end{tabular}


Table 6 Condiments or ingredients in drinks modulate PI3K/Akt and/or GSK3 activities

\begin{tabular}{|c|c|c|c|}
\hline Nutrient & Model system & Observed effects & Ref. \\
\hline \multicolumn{4}{|l|}{ Condiments } \\
\hline \multirow[t]{5}{*}{ Capsaicin } & aTRPV1-KO and wild-type C57BL/6 mice. & $\begin{array}{l}\text { Exert its effect through the capsaicin receptor that } \\
\text { is the transient receptor potential cation channel } \\
\text { subfamily } \vee \text { member } 1 \text { (TRPV1). }\end{array}$ & [199] \\
\hline & Human prostate cancer cells. & $\begin{array}{l}\text { Regulate PI3K/Akt pathway in cultured cells and } \\
\text { can activate microglia in mouse spine cord at a } \\
\text { very low concentration. }\end{array}$ & [200] \\
\hline & Rat spinal cord & $\begin{array}{l}\text { ERK activation is detected in microglia of animal } \\
\text { spine cord by capsaicin stimulation. }\end{array}$ & [201] \\
\hline & $\begin{array}{l}\text { SD rats, astrocytes and microglia from } \\
\text { the rats, human microglia cells. }\end{array}$ & $\begin{array}{l}\text { Capsaicin-activated TRPV1 mediates microglia } \\
\text { death via calcium signaling. }\end{array}$ & [202] \\
\hline & Human colorectal cancer cells. & $\begin{array}{l}\text { Increase association of c/EBP } \beta \text { and GSK3 } \beta \text {, } \\
\text { which is suggested to mediate capsaicin- } \\
\text { induced apoptosis. }\end{array}$ & [203] \\
\hline \multirow[t]{3}{*}{$\begin{array}{l}\text { Monosodium glutamate } \\
\text { (MSG) }\end{array}$} & Rodent striatal cholinergic interneurons. & $\begin{array}{l}\text { Contain glutamate which is a non-essential } \\
\text { amino acid and its receptor is glutamate } \\
\text { receptor, belonging to GPCR. }\end{array}$ & [204] \\
\hline & Animal nervous systems & $\begin{array}{l}\text { Neurotransmitters in the brain; whether MSG } \\
\text { clinically associates with neurologic diseases } \\
\text { remains to be studied. }\end{array}$ & [205] \\
\hline & $\begin{array}{l}\text { SD rats, mouse hippocampal } \\
\text { neuronal cells, hippocampal } \\
\text { neurons and brain cortex from SD rats. }\end{array}$ & $\begin{array}{l}\text { Induce neurodegeneration is suggested via } \\
\text { PI3K Akt pathway regulation and injection } \\
\text { of glutamate into animals generates } \\
\text { neurotoxicity via GSK3 } \beta \text {. }\end{array}$ & $\begin{array}{l}{[147,148,} \\
206]\end{array}$ \\
\hline Ingredients in drinks & Animal nervous systems. & $\begin{array}{l}\text { A central nervous system (CNS) stimulant } \\
\text { and cause biological effects via adenosine } \\
\text { receptors that belong to GPCR. }\end{array}$ & [207-209] \\
\hline \multirow[t]{2}{*}{ Caffeine } & $\begin{array}{l}\text { Human neuroblastoma cells, HeLa cells, } \\
\text { mouse neural crest cells, mouse adipocytes. }\end{array}$ & $\begin{array}{l}\text { Activate PI3K/Akt pathway and prevent cell death; } \\
\text { or induce cell apoptosis by suppressing PI3K/Akt } \\
\text { signaling and decrease phosphorylation } \\
\text { levels of Akt/GSK3 } 3 \text {. }\end{array}$ & {$[210-212]$} \\
\hline & Patients. & $\begin{array}{l}\text { Excess caffeine can lead to caffeine intoxication } \\
\text { (i.e. overstimulation of CNS). }\end{array}$ & [213] \\
\hline \multirow[t]{5}{*}{ Ethanol } & $\begin{array}{l}\text { Ethanol-induced fatty liver in mice, } \\
{ }^{a} \text { AA and ANA rats. }\end{array}$ & $\begin{array}{l}\text { Presented in liquor can acutely induce } \\
\text { hepatosteatosis, a process associated } \\
\text { with PIJK/Akt activation and phosphorylation } \\
\text { levels of Akt and GSK3 } \beta \text { in the rat cortex. }\end{array}$ & {$[214,215]$} \\
\hline & Human vascular endothelial cells. & $\begin{array}{l}\text { Low concentrations of ethanol activate PI3K Akt } \\
\text { signaling, inhibiting GSK3 activity, whereas high } \\
\text { concentrations of ethanol induce caspase-3 } \\
\text { activation and increases apoptosis }\end{array}$ & [216] \\
\hline & Human cells, C57BL/6 mice. & $\begin{array}{l}\text { Ethanol is metabolized to acetaldehyde by alcohol } \\
\text { dehydrogenase in the body, and acetaldehyde is } \\
\text { further metabolized by aldehyde } \\
\text { dehydrogenases (ALDH). }\end{array}$ & {$[217,218]$} \\
\hline & Human hepatic stellate cells. & $\begin{array}{l}\text { The acetaldehyde-enhanced gene expression } \\
\text { requires PI3K activation. }\end{array}$ & [219-221] \\
\hline & C57BL/6 mice & $\begin{array}{l}\text { Ethanol administration reduces phosphorylation } \\
\text { levels of Akt and GSK3 } \beta \text {, which is aggravated in } \\
\text { cardiomyocyte without ALDH-2. }\end{array}$ & [218] \\
\hline Tea & Components analyzed. & $\begin{array}{l}\text { Have ingredients including caffein, polyphenols } \\
\text { and catechin containing abundant } \\
\text { epigallocatechin gallate (EGCG). }\end{array}$ & [222] \\
\hline Tea polyphenols & $\begin{array}{l}\text { Mouse skin epithelial cells, human } \\
\text { normal and keloid fibroblasts, } \\
\text { the cultured human keloid model. } \\
\text { Humans. }\end{array}$ & $\begin{array}{l}\text { Have inhibitory effects on PI3K pathway and suppress } \\
\text { PI3K Akt proteins expression and/or Akt activity in vitro } \\
\text { and in vivo in prostate cancer models, may play roles } \\
\text { in prevention of prostate cancer. }\end{array}$ & {$[223-225]$} \\
\hline
\end{tabular}


Table 6 Condiments or ingredients in drinks modulate PI3K/Akt and/or GSK3 activities (Continued)

\begin{tabular}{|c|c|c|c|}
\hline \multirow[t]{2}{*}{ EGCG } & $\begin{array}{l}\text { Human hepatocyte derived cellular } \\
\text { carcinoma cells, human pancreatic } \\
\text { carcinoma cells. }\end{array}$ & $\begin{array}{l}\text { Block cell growth and induces cell apoptosis } \\
\text { via inhibition of VEGF signaling pathway } \\
\text { including Akt or downregulation of Akt activity. }\end{array}$ & {$[226,227]$} \\
\hline & $\begin{array}{l}\text { Human alveolar basal epithelial cells, } \\
\text { human neuroblastoma cells } \\
\text { expressing }{ }^{\text {b APP-C } 99 .}\end{array}$ & $\begin{array}{l}\text { Raise cell viability by its induction of Akt activity } \\
\text { and suppression of GSK3 } 3 \text { activity and inhibit } \\
\beta \text {-amyloid-induced neurotoxicity by suppression } \\
\text { of GSK3 } \beta \text { activation. }\end{array}$ & {$[228,229]$} \\
\hline
\end{tabular}

\footnotetext{
${ }^{a}$ AA and ANA: AA (Alko, Alcohol) line of rats which prefer $10 \%$ alcohol to water, and the ANA (Alko, Non-Alcohol) line of rats which are given only water

${ }^{b}$ APP-C99: an amyloid precursor protein fragment
}

not there is a cross talk between the two regulatory pathways remains to be determined. Palmitic acid-treated cells show decrease in Akt/PI3K/GSK3 sensitivity [68], which is a good lipid model to study the crosstalk between the two pathways.
Development of drugs targeting GSK3 inhibition is recently making progress $[9,93]$, including synthetic inhibitors that delay progress of diseases $[10,94,95]$ and natural inhibitor such as lithium that can extend Drosophila lifespan by $16 \%$ [92]. However, high concentration of

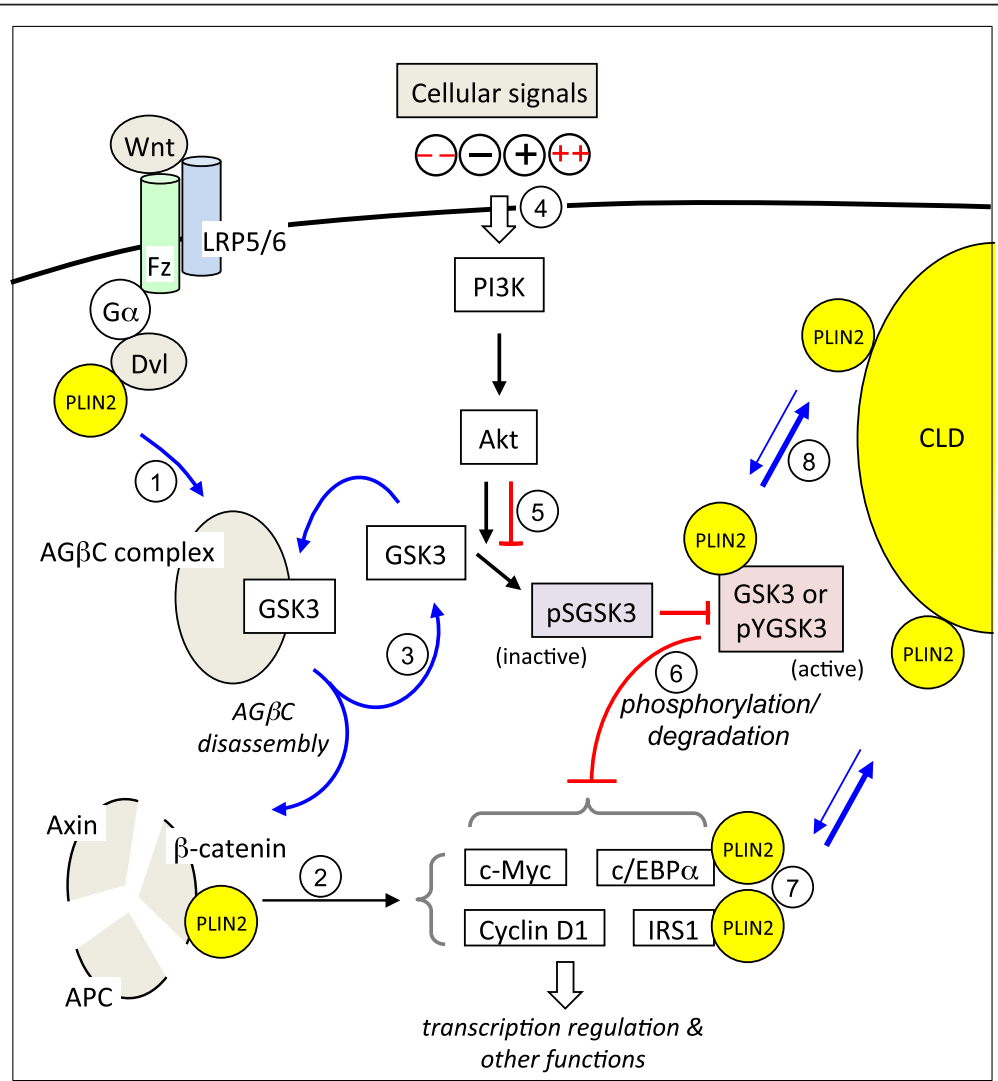

Fig. 1 Dual regulation of GSK3 by the PI3K/Akt/GSK3 pathway and PLIN2. Upon Wnt stimulation, the axin-GSK3- $\beta$-catenin complex (AGBC) is disassembled and the process is dependent of PLIN2 (denoted by curvy blue arrows) [1]. The released $\beta$-catenin from the AG $\beta C$ complex activates transcription of factors involved in cell growth/survival (e.g. c-Myc, c/EBPa, and cyclin D1) or in insulin signaling (e.g. IRS1) [2], whereas the released GSK3 from the AGBC complex can be present in cytosol or recycle back to the AGBC complex [3]. The GSK3 activity is regulated mainly through the PI3K/Akt pathway that relays extracellular and intracellular (not shown) signals; - and + denote normal inhibitory and stimulatory signals, respectively, whereas -- and ++ (in red) denote over-inhibitory (e.g. the potency of the LY compounds used in (Ref 216)) and over-stimulatory (e.g. the potency of VEGF used in (Ref 5)) signals, respectively [4]. Different stages of kinase insensitivity and uncontrolled GSK3 activation are summarized in Table 1. Under - and -- conditions, the respective pSGSK3 levels are reduced but GSK3/pYGSK3 levels are increased (denoted by red blockage between the two) [5], perhaps inducing moderate and high activities of GSK3, respectively. Under ++ conditions, all the kinases tend to become insensitive (denoted by red blockages), generating unbridled GSK3 activity (Table 1) that can phosphorylate its substrates and render their degradation [6]. Accumulation of cytosolic lipid droplets (CLD) alters the association of PLIN2 and its binding proteins such as Dishevelled (DVI), $\beta$-catenin, c/EBPa, and IRS1 [7]. The bold blue lines denote high affinity between PLIN2 and CLD [8]. LRP5/6: lipoprotein receptor-related proteins 5/6; Fz, frizzled; Ga, guanine nucleotide binding protein a subunit 
lithium appears to be toxic [92] and over-suppression of GSK3 activity increases the risk of developing cancer $[6,10]$. It merits further investigation to ascertain whether or not GSK3 inhibition could be a druggable target for clinical treatments.

To conclude, the overstimulation-induced kinase insensitivity that leads to uncontrolled GSK3 overactivation represents a key cellular/molecular mechanism that is intimately associated with aging and many age-related chronic diseases. As an ancient Taoism saying goes, the extremity reached, the course reversed (物 极必反). Factors contributing to such an overstimulation range from life style (unbalanced diets), habit and behavior (including medication) to psychological conditions (including negative emotions or ecstasy, an extremely positive emotion). Therefore, preventing from overactivation of GSK3 in the body, through adoption of healthy habits/lifestyles including balanced diets and a positive attitude, does a great favor to our health.

\section{Abbreviations}

AA and ANA, AA (Alko, Alcohol) line of rats which prefer $10 \%$ alcohol to water, and the ANA (Alko, Non-Alcohol) line of rats which are given only water; ADRP, adipose-differentiation related protein; AGBC, axin/GSK3 $\beta / \beta$-catenin complex; AIDS, acquired immune deficiency syndrome; ALDH, aldehyde dehydrogenases; APP/PS1, amyloid precursor protein/presenilin-1; APP-C99, an amyloid precursor protein fragment; C/EBP, CCAAT enhancing binding protein; CK II, casein kinase 2; CLN, ceroid-lipofuscinosis neuronal protein; CNS, central nervous system; COX-2, cyclooxygenase-2, prostaglandin-endoperoxide synthase 2; CVD, cardiovascular diseases; Dvl2, dishevelled 2; EDTA, ethylenediaminetetraacetic acid; EGCG, epigallocatechin gallate; ERK, extracellular signal-regulated kinases; Fz, Frizzled; Gas6, growth arrest-specific 6; GPCR, G-protein coupled receptors; GSK3, glycogen synthase kinase 3; Ga, guanine nucleotide binding protein a subunit; Hca2, Niacin receptor 1; HIV, human immunodeficiency virus; HRPE, human retinal pigment epithelial cells; IGF-1, insulin-like growth factor 1; IL17RC, interleukin 17 receptor C; IRS1, insulin receptor substrate 1; KKAy mice, The KK-Ay mouse is a type 2 diabetic model that exhibits marked obesity, glucose intolerance, severe insulin resistance, dyslipidemia, and hypertension; LRP, lipoprotein receptor-related proteins; MSG, monosodium glutamate; $\mathrm{NaCl}$, sodium chloride; NF-KB, nuclear factor kappa-light-chain-enhancer of activated B cells; Nrf2, nuclear factor (erythroid derived 2)-like 2; NSF, $\mathrm{N}$-ethylmaleimide-sensitive factor; PBMC, peripheral blood mononuclear cells; PDK1, phosphoinositide-dependent kinase-1; PI3K, phosphoinositide 3-kinase; PK, protein kinase; PLIN, perilipin; Protein S, S-protein; pSGSK3, serine- phosphorylated form of GSK3; pYGSK3, tyrosine-phosphorylated form of GSK3; RTK, receptors of tyrosine kinase; SD, Sprague Dawley; siRNA, short interfering RNA; SNAP, soluble NSF attachment protein; SNARE, SNAP (soluble NSF attachment protein) receptor; T2D, type 2 diabetes; TCF, T-cell factor; TRPV1, transient receptor potential cation channel subfamily $\vee$ member 1; VEGF, vascular endothelial growth factor; WNK, with-no-lysine kinase

\section{Acknowledgements}

This work is supported by an operating grant (MOP 123279) from the Canadian Institutes for Health Research.

\section{Availability of data and material}

Not applicable.

\section{Authors' contributions}

Both $X L$ and $Z Y$ drafted, edited, and final approved the manuscript.

\section{Competing interests}

The authors declare that they have no competing interests.
Received: 5 May 2016 Accepted: 21 July 2016

Published online: 04 August 2016

\section{References}

1. Li DW, Liu ZQ, Chen W, Yao M, Li GR. Association of glycogen synthase kinase-3 $\beta$ with Parkinson's disease. Mol Med Rep. 2014;9:2043-50.

2. Beurel E, Grieco SF, Jope RS. Glycogen synthase kinase-3 (GSK3): regulation, actions, and diseases. Pharmacol Ther. 2015;148:114-31.

3. Biondi RM, Nebreda AR. Signaling specificity of Ser/Thr protein kinases through docking-site-mediated interactions. Biochem J. 2003;372:1-13.

4. Tejeda-Muñoz N, González-Aguilar H, Santoyo-Ramos P, Castañeda-Patlán MC, Robles-Flores M. Glycogen synthase kinase $3 \beta$ is positively regulated by protein kinase C(-mediated phosphorylation induced by Wnt agonists. Mol Cell Biol. 2015;36:731-41.

5. Liu X. Overstimulation can create health problems due to increases of PI/ 3K/Akt/GSK3 insensitivity and GSK3 activity. SpringerPlus. 2014;3:356.

6. Liu X, Lu X, Song K, Blackman MR. Natural functions of PLIN2 mediating Wnt/LiCl signaling and GSK3/GSK3 substrates-related effects are modulated by lipid. Mol Cell Biol. 2015;36:421-37.

7. Frödin M, Antal TL, Dümmler BA, Jensen CJ, Deak M, Gammeltoft S, Biondi RM. A phosphoserine/threonine-binding pocket in AGC kinases and PDK1 mediates activation by hydrophobic motif phosphorylation. EMBO J. 2002;21:5396-407.

8. Park J, Leong ML, Buse P, Maiyar AC, Firestone GL, Hemmings BA. Serum and glucocorticoid-inducible kinase (SGK) is a target of the PI 3-kinasestimulated signaling pathway. EMBO J. 1999;18:3024-33.

9. Jope RS, Roh MS. Glycogen synthase kinase-3 (GSK3) in psychiatric diseases and therapeutic interventions. Curr Drug Targets. 2006;7:1421-34.

10. Eldar-Finkelman $\mathrm{H}$. Glycogen synthase kinase 3: an emerging therapeutic target. Trends Mol Med. 2002;8:126-32.

11. Beurel E. Regulation by glycogen synthase kinase-3 of inflammation and T cells in CNS diseases. Front Mol Neurosci. 2011;31(4):18.

12. Fang $X, Y$ U SX, Lu Y, Bast Jr RC, Woodgett JR, Mills GB. Phosphorylation and inactivation of glycogen synthase kinase 3 by protein kinase A. Proc Natl Acad Sci U S A. 2000;97:11960-5.

13. Moore SF, van den Bosch MT, Hunter RW, Sakamoto K, Poole AW, Hers I. Dual regulation of glycogen synthase kinase 3 (GSK3)a/ $\beta$ by protein kinase $\mathrm{C}(\mathrm{PKC}) \mathrm{a}$ and Akt promotes thrombin-mediated integrin allbB3 activation and granule secretion in platelets. J Biol Chem. 2013;288:3918-28.

14. Jope RS, Johnson GV. The glamour and gloom of glycogen synthase kinase3. Trends Biochem Sci. 2004;29:95-102.

15. Watcharasit P, Bijur GN, Zmijewski JW, Song L, Zmijewska A, Chen X, Johnson GV, Jope RS. Direct, activating interaction between glycogen synthase kinase-3 $\beta$ and p53 after DNA damage. Proc Natl Acad Sci U S A. 2002;99:7951-5.

16. Grimes CA, Jope RS. CREB DNA binding activity is inhibited by glycogen synthase kinase-3 $\beta$ and facilitated by lithium. J Neurochem. 2001;78:1219-32.

17. Naderali EK, Ratcliffe SH, Dale MC. Obesity and Alzheimer's disease: a link between body weight and cognitive function in old age. Am J Alzheimers Dis Other Demen. 2010;24:445-9.

18. Pi-Sunyer FX. Health implications of obesity. Am J Clin Nutr. 1991;53:1595S-603S.

19. Blackman MR, Sorkin JD, Münzer T, Bellantoni MF, Busby-Whitehead J, Stevens TE, Jayme J, O'Connor KG, Christmas C, Tobin JD, Stewart KJ, Cottrell E, St Clair C, Pabst KM, Harman SM. Growth hormone and sex steroid administration in healthy aged women and men: a randomized controlled trial. JAMA. 2002;288:2282-92.

20. Wei L, Liu B, Tuo J, Shen D, Chen P, Li Z, Liu X, Ni J, Dagur P, Sen HN, Jawad S, Ling D, Park S, Chakrabarty S, Meyerle C, Agron E, Ferris 3rd FL, Chew EY, McCoy JP, Blum E, Francis PJ, Klein ML, Guymer RH, Baird PN, Chan CC, Nussenblatt RB. Hypomethylation of the IL17RC promoter associates with age-related macular degeneration. Cell Rep. 2012;2:1151-8.

21. Denckla WD. Role of the pituitary and thyroid glands in the decline of minimal O2 consumption with age. J Clin Invest. 1974;53:572-81.

22. Kuzman JA, Vogelsang KA, Thomas TA, Gerdes AM. Thyroxine activates Akt signaling in the heart. J Mol Cell Cardiol. 2005;39:251-8.

23. Díaz ME, González L, Miquet JG, Martínez CS, Sotelo Al, Bartke A, Turyn D. Growth hormone modulation of EGF-induced PI3K-Akt pathway in mice liver. Cell Signal. 2012;24:514-23.

24. Ogihara T, Asano T, Ando K, Chiba Y, Sekine N, Sakoda H, Anai M, Onishi Y, Fujishiro M, Ono H, Shojima N, Inukai K, Fukushima Y, Kikuchi M, Fujita T. Insulin resistance with enhanced insulin signaling in high-salt diet-fed rats. Diabetes. 2001;50:573-83. 
25. Sztalryd C, Kimmel AR. Perilipins: lipid droplet coat proteins adapted for tissue-specific energy storage and utilization, and lipid cytoprotection. Biochimie. 2014;96:96-101.

26. Hickenbottom SJ, Kimmel AR, Londos C, Hurley JH. Structure of a lipid droplet protein; the PAT family member TIP47. Structure. 2004;12:1199-207.

27. Hynson RM, Jeffries CM, Trewhella J, Cocklin S. Solution structure studies of monomeric human TIP47/perilipin-3 reveal a highly extended conformation. Proteins. 2012;80:2046-55.

28. Díaz E, Pfeffer SR. TIP47: a cargo selection device for mannose 6-phosphate receptor trafficking. Cell. 1998;93:433-43.

29. Brasaemle DL, Wolins NE. Packaging of fat: an evolving model of lipid droplet assembly and expansion. J Biol Chem. 2012;287:2273-9.

30. Varela GM, Antwi DA, Dhir R, Yin X, Singhal NS, Graham MJ, Crooke RM, Ahima RS. Inhibition of ADRP prevents diet-induced insulin resistance. Am J Physiol Gastrointest Liver Physiol. 2008;295:G621-8.

31. Chang BH, Li L, Paul A, Taniguchi S, Nannegari V, Heird WC, Chan L. Protection against fatty liver but normal adipogenesis in mice lacking adipose differentiation-related protein. Mol Cell Biol. 2006;26:1063-76.

32. McManaman JL, Bales ES, Orlicky DJ, Jackman M, MacLean PS, Cain S, Crunk AE, Mansur A, Graham CE, Bowman TA, Greenberg AS. Perilipin-2-null mice are protected against diet-induced obesity, adipose inflammation, and fatty liver disease. J Lipid Res. 2013;54:1346-59.

33. Bosma M, Hesselink MK, Sparks LM, Timmers S, Ferraz MJ, Mattijssen F, van Beurden D, Schaart G, de Baets MH, Verheyen FK, Kersten S, Schrauwen P. Perilipin 2 improves insulin sensitivity in skeletal muscle despite elevated intramuscular lipid levels. Diabetes. 2012;61:2679-90.

34. Russell TD, Palmer CA, Orlicky DJ, Bales ES, Chang BH, Chan L, McManaman J. Mammary glands of adipophilin-null mice produce an amino-terminally truncated form of adipophilin that mediates milk lipid droplet formation and secretion. J Lipid Res. 2008;49:206-16.

35. Larigauderie G, Cuaz-Pérolin C, Younes AB, Furman C, Lasselin C, Copin C, Jaye M, Fruchart JC, Rouis M. Adipophilin increases triglyceride storage in human macrophages by stimulation of biosynthesis and inhibition of $\beta$ oxidation. FEBS J. 2006;273:3498-510.

36. Fukushima M, Enjoji M, Kohjima M, Sugimoto R, Ohta S, Kotoh K, Kuniyoshi M, Kobayashi K, Imamura M, Inoguchi T, Nakamuta M, Nawata H. Adipose differentiation related protein induces lipid accumulation and lipid droplet formation in hepatic stellate cells. In Vitro Cell Dev Biol Anim. 2005;41:321-4.

37. Listenberger LL, Ostermeyer-Fay AG, Goldberg EB, Brown WJ, Brown DA. Adipocyte differentiation-related protein reduces the lipid droplet association of adipose triglyceride lipase and slows triacylglycerol turnover. J Lipid Res. 2007;48:2751-61.

38. Senthivinayagam S, Mclntosh AL, Moon KC, Atshaves BP. Plin2 inhibits cellular glucose uptake through interactions with SNAP23, a SNARE complex protein. PLoS One. 2013;8:e73696.

39. Liu X, Rubin JS, Kimmel AR. Rapid, Wnt-induced changes in GSK3 $\beta$ associations that regulate $\beta$-catenin stabilization are mediated by $\mathrm{Ga}$ proteins. Curr Biol. 2005;15:1989-97.

40. Xu G, Sztalryd C, Lu X, Tansey JT, Gan J, Dorward H, Kimmel AR, Londos C. Post-translational regulation of adipose differentiation-related protein by the ubiquitin/proteasome pathway. J Biol Chem. 2005;280:42841-7.

41. Chang BH, Li L, Saha P, Chan L. Absence of adipose differentiation related protein upregulates hepatic VLDL secretion, relieves hepatosteatosis, and improves whole body insulin resistance in leptin-deficient mice. J Lipid Res. 2010;51:2132-42.

42. Tirinato L, Liberale C, Di Franco S, Candeloro P, Benfante A, La Rocca R, Potze L, Marotta R, Ruffilli R, Rajamanickam VP, Malerba M, De Angelis F, Falqui A, Carbone E, Todaro M, Medema JP, Stassi G, Di Fabrizio E. Lipid droplets: a new player in colorectal cancer stem cells unveiled by spectroscopic imaging. Stem Cells. 2015;33:35-44.

43. Ho L, Qin W, Pompl PN, Xiang Z, Wang J, Zhao Z, Peng Y, Cambareri G, Rocher A, Mobbs CV, Hof PR, Pasinetti GM. Diet-induced insulin resistance promotes amyloidosis in a transgenic mouse model of Alzheimer's disease. FASEB J. 2004;18:902-4.

44. Diehl JA, Cheng M, Roussel MF, Sherr CJ. Glycogen synthase kinase-3 $\beta$ regulates cyclin D1 proteolysis and subcellular localization. Genes Dev. 1998; 12:3499-511.

45. Leng S, Zhang W, Zheng Y, Liberman Z, Rhodes CJ, Eldar-Finkelman H, Sun $X J$. Glycogen synthase kinase $3 \beta$ mediates high glucose-induced ubiquitination and proteasome degradation of insulin receptor substrate 1. J Endocrinol. 2010;206:171-81.
46. Gomis A, Soriano S, Belmonte C, Viana F. Hypoosmotic- and pressure-induced membrane stretch activate TRPC5 channels. J Physiol. 2008:586:5633-49.

47. Danciu TE, Adam RM, Naruse K, Freeman MR, Hauschka PV. Calcium regulates the PI3K-Akt pathway in stretched osteoblasts. FEBS Lett. 2003;536:193-7.

48. Liu ZM, Chen GG, Vlantis AC, Tse GM, Shum CK, van Hasselt CA. Calciummediated activation of PI3K and p53 leads to apoptosis in thyroid carcinoma cells. Cell Mol Life Sci. 2007;64:1428-36.

49. Chan PM, Lim L, Manser E. PAK is regulated by PI3K, PIX, CDC42, and PP2Ca and mediates focal adhesion turnover in the hyperosmotic stress-induced p38 pathway. J Biol Chem. 2008;283:24949-61.

50. Bin BH, Bhin J, Yang SH, Choi DH, Park K, Shin DW, Lee AY, Hwang D, Cho EG, Lee TR. Hyperosmotic stress reduces melanin production by altering melanosome formation. PLoS One. 2014;9:e105965.

51. Lee MS, Yoon HD, Kim Jl, Choi JS, Byun DS, Kim HR. Dioxinodehydroeckol inhibits melanin synthesis through PI3K/Akt signalling pathway in a-melanocytestimulating hormone-treated B16F10 cells. Exp Dermatol. 2012;21:471-3.

52. Song YC, Lee $Y$, Kim HM, Hyun MY, Lim YY, Song KY, Kim BJ. Berberine regulates melanin synthesis by activating PI3KJAKT, ERK and GSK3 $\beta$ in B16F10 melanoma cells. Int J Mol Med. 2015;35:1011-6.

53. Anthony JC, Anthony TG, Kimball SR, Vary TC, Jefferson LS. Orally administered leucine stimulates protein synthesis in skeletal muscle of postabsorptive rats in association with increased elF4F formation. J Nutr. 2000;130:139-45.

54. Sancak Y, Peterson TR, Shaul YD, Lindquist RA, Thoreen CC, Bar-Peled L, Sabatini DM. The Rag GTPases bind raptor and mediate amino acid signaling to mTORC1. Science. 2008;320:1496-501.

55. Peyrollier K, Hajduch E, Blair AS, Hyde R, Hundal HS. L-leucine availability regulates phosphatidylinositol 3-kinase, p70 S6 kinase and glycogen synthase kinase-3 activity in L6 muscle cells: evidence for the involvement of the mammalian target of rapamycin (mTOR) pathway in the L-leucineinduced up-regulation of system A amino acid transport. Biochem J. 2000; 350 Pt 2:361-8

56. Lutz J. Calcium balance and acid-base status of women as affected by increased protein intake and by sodium bicarbonate ingestion. Am J Clin Nutr. 1984;39:281-8.

57. Barzel US, Massey LK. Excess dietary protein can adversely affect bone. J Nutr. 1998;128:1051-3.

58. Chen SD, Chen YB, Peng Y, Xu J, Chen SS, Zhang JL, Li ZZ, Tan Z. Role of PI3K Akt signaling in the protective effect of magnesium sulfate against ischemiaperfusion injury of small intestine in rats. Chin Med J (Engl). 2010;123:1447-52.

59. Hu S, Chang Y, He M, Wang J, Wang Y, Xue C. Fucosylated chondroitin sulfate from sea cucumber improves insulin sensitivity via activation of PI3K PKB pathway. J Food Sci. 2014;79:H1424-9.

60. Vlodavsky I, Ilan N, Naggi A, Casu B. Heparanase: structure, biological functions, and inhibition by heparin-derived mimetics of heparan sulfate. Curr Pharm Des. 2007;13:2057-73.

61. Oba I, Mori T, Chida M, Kurasawa N, Naganuma E, Sato E, Koizumi K, Sato S, Tsuchikawa M, Ito S. Glucose and insulin response to peritoneal dialysis fluid in diabetic and nondiabetic peritoneal dialysis patients. Adv Perit Dial. 2015;31:11-6.

62. Tomás E, Lin YS, Dagher Z, Saha A, Luo Z, Ido Y, Ruderman NB. Hyperglycemia and insulin resistance: possible mechanisms. Ann N Y Acad Sci. 2002;967:43-51.

63. Venkatachalam K, Mummidi S, Cortez DM, Prabhu SD, Valente AJ, Chandrasekar B. Resveratrol inhibits high glucose-induced PI3K/Akt/ERKdependent interleukin-17 expression in primary mouse cardiac fibroblasts. Am J Physiol Heart Circ Physiol. 2008;294:H2078-87.

64. Jope RS, Yuskaitis CJ, Beurel E. Glycogen synthase kinase-3 (GSK3): inflammation, diseases, and therapeutics. Neurochem Res. 2007;32:577-95.

65. Yonezawa T, Kurata R, Yoshida K, Murayama MA, Cui X, Hasegawa A. Free fatty acids-sensing $\mathrm{G}$ protein-coupled receptors in drug targeting and therapeutics. Curr Med Chem. 2013;20:3855-71.

66. Pu J, Liu P. Fatty acids stimulate glucose uptake by the PI3K/AMPK/Akt and PI3KJERK1/2 pathways, chapter 4 of protein phosphorylation in human health, book edited by Cai Huang. ISBN 978-953-51-0737-8. InTech: Science, Technology and Medicine open access (Sep. 6, 2012).

67. Kruszynska YT, Worrall DS, Ofrecio J, Frias JP, Macaraeg G, Olefsky JM. Fatty acid-induced insulin resistance: decreased muscle PI3K activation but unchanged Akt phosphorylation. J Clin Endocrinol Metab. 2002;87:226-34.

68. Yang Y, Li W, Li Y, Wang Q, Gao L, Zhao J. Dietary Lycium barbarum polysaccharide induces Nrf2/ARE pathway and ameliorates insulin resistance induced by high-fat via activation of PI3K/AKT signaling. Oxid Med Cell Longev. 2014;2014:145641. 
69. Liu X, Choi RY, Jawad SM, Arnold JT. Androgen-induced PSA expression requires not only activation of AR but also endogenous IGF-I or IGF-I/PI3KJAkt signaling in human prostate cancer epithelial cells. Prostate. 2011;71:766-77.

70. Yang W, Luo Y, Tang R, Zhang H, Ye Y, Xiang L, Qi J. Neuritogenic monoglyceride derived from the constituent of a marine fish for activating the PI3K/ERK/CREB signalling pathways in PC12 cells. Int J Mol Sci. 2013;14:24200-10.

71. Miao B, Skidan I, Yang J, Lugovskoy A, Reibarkh M, Long K, Brazell T, Durugkar KA, Maki J, Ramana CV, Schaffhausen B, Wagner G, Torchilin V, Yuan J, Degterev A. Small molecule inhibition of phosphatidylinositol-3,4,5triphosphate (PIP3) binding to pleckstrin homology domains. Proc Natl Acad Sci U S A. 2010;107:20126-31.

72. Sekine S, Terada S, Aoyama T. Medium-chain triacylglycerol suppresses the decrease of plasma albumin level through the insulin-Akt-mTOR pathway in the livers of malnourished rats. J Nutr Sci Vitaminol (Tokyo). 2013;59:123-8.

73. Eldar-Finkelman H, Schreyer SA, Shinohara MM, LeBoeuf RC, Krebs EG. Increased glycogen synthase kinase-3 activity in diabetes- and obesityprone C57BL/6J mice. Diabetes. 1999;48:1662-6.

74. Rao R, Hao CM, Redha R, Wasserman DH, McGuinness OP, Breyer MD. Glycogen synthase kinase 3 inhibition improves insulin-stimulated glucose metabolism but not hypertension in high-fat-fed C57BL/6J mice. Diabetologia. 2007;50:452-60.

75. Sylvester PW, Ayoub NM. Tocotrienols target PI3K/Akt signaling in antibreast cancer therapy. Anticancer Agents Med Chem. 2013;13:1039-47.

76. Ni J, Wen X, Yao J, Chang HC, Yin Y, Zhang M, Xie S, Chen M, Simons B, Chang P, di Sant'Agnese A, Messing EM, Yeh S. Tocopherol-associated protein suppresses prostate cancer cell growth by inhibition of the phosphoinositide 3-kinase pathway. Cancer Res. 2005;65:9807-16.

77. Samant GV, Sylvester PW. gamma-Tocotrienol inhibits ErbB3-dependent PI3K/Akt mitogenic signalling in neoplastic mammary epithelial cells. Cell Prolif. 2006:39:563-74.

78. Poh TW, Pervaiz S. LY294002 and LY303511 sensitize tumor cells to druginduced apoptosis via intracellular hydrogen peroxide production independent of the phosphoinositide 3-kinase-Akt pathway. Cancer Res. 2005;65:6264-74.

79. Chen L, Khillan JS. A novel signaling by vitamin A/retinol promotes self renewal of mouse embryonic stem cells by activating PI3K/Akt signaling pathway via insulin-like growth factor-1 receptor. Stem Cells. 2010;28:57-63.

80. López-Carballo G, Moreno L, Masiá S, Pérez P, Barettino D. Activation of the phosphatidylinositol 3-kinase/Akt signaling pathway by retinoic acid is required for neural differentiation of SH-SY5Y human neuroblastoma cells. J Biol Chem. 2002;277:25297-304.

81. Ma Y, Feng Q, Sekula D, Diehl JA, Freemantle SJ, Dmitrovsky E. Retinoid targeting of different D-type cyclins through distinct chemopreventive mechanisms. Cancer Res. 2005;65:6476-83.

82. Bjelakovic G, Nikolova D, Gluud C. Meta-regression analyses, meta-analyses, and trial sequential analyses of the effects of supplementation with $\beta$ carotene, vitamin $\mathrm{A}$, and vitamin $\mathrm{E}$ singly or in different combinations on all-cause mortality: do we have evidence for lack of harm? PLoS One. 2013; 8:e74558.

83. Liu X, Allen JD, Arnold JT, Blackman MR. Lycopene inhibits IGF-I signal transduction and growth in normal prostate epithelial cells by decreasing DHT-modulated IGF-I production in co-cultured reactive stromal cells. Carcinogenesis. 2008:29:816-23.

84. Oliver VF, Franchina M, Jaffe AE, Branham KE, Othman M, Heckenlively JR, Swaroop A, Campochiaro B, Vote BJ, Craig JE, Saffery R, Mackey DA, Qian J, Zack DJ, Hewitt AW, Merbs SL. Hypomethylation of the IL17RC promoter in peripheral blood leukocytes is not a hallmark of age-related macular degeneration. Cell Rep. 2013;5:1527-35.

85. Schrager JA, Der Minassian V, Marsh JW. HIV Nef increases T cell ERK MAP kinase activity. J Biol Chem. 2002;277:6137-42.

86. Blagoveshchenskaya AD, Thomas L, Feliciangeli SF, Hung CH, Thomas G. HIV-1 Nef downregulates MHC-I by a PACS-1- and PI3K-regulated ARF6 endocytic pathway. Cell. 2002;111:853-66.

87. Chugh P, Bradel-Tretheway B, Monteiro-Filho CM, Planelles V, Maggirwar SB, Dewhurst S, Kim B. Akt inhibitors as an HIV-1 infected macrophage-specific anti-viral therapy. Retrovirology. 2008;5:11.

88. Lucas A, Kim Y, Rivera-Pabon O, Chae S, Kim DH, Kim B. Targeting the PI3K Akt cell survival pathway to induce cell death of HIV-1 infected macrophages with alkylphospholipid compounds. PLoS One. 2010;5:e13121.

89. Basbaum Al, Bautista DM, Scherrer G, Julius D. Cellular and molecular mechanisms of pain. Cell. 2009;139:267-84.
90. Zhang JM, An J. Cytokines, inflammation, and pain. Int Anesthesiol Clin. 2007;45:27-37.

91. Kotliarova S, Pastorino S, Kovell LC, Kotliarov Y, Song H, Zhang W, Bailey R, Maric D, Zenklusen JC, Lee J, Fine HA. Glycogen synthase kinase-3 inhibition induces glioma cell death through c-MYC, nuclear factor-kappa B, and glucose regulation. Cancer Res. 2008;68:6643-51.

92. Castillo-Quan JI, Li L, Kinghorn KJ, Ivanov DK, Tain LS, Slack C, Kerr F, Nespital T, Thornton J, Hardy J, Bjedov I, Partridge L. Lithium promotes longevity through GSK3/NRF2-dependent hormesis. Cell Rep. 2016;15:638-50.

93. Pandey MK, DeGrado TR. Glycogen synthase kinase-3 (GSK-3)-targeted therapy and imaging. Theranostics. 2016;6:571-93.

94. Motawi TM, Bustanji Y, El-Maraghy SA, Taha MO, Al Ghussein MA. Naproxen and cromolyn as new glycogen synthase kinase $3 \beta$ inhibitors for amelioration of diabetes and obesity: an investigation by docking simulation and subsequent in vitro/in vivo biochemical evaluation. J Biochem Mol Toxicol. 2013;27:425-36.

95. Xie CL, Lin JY, Wang MH, Zhang Y, Zhang SF, Wang XJ, Liu ZG. Inhibition of Glycogen Synthase Kinase-3 $\beta$ (GSK-3 3 ) as potent therapeutic strategy to ameliorates L-dopa-induced dyskinesia in 6-OHDA parkinsonian rats. Sci Rep. 2016;6:23527.

96. Padiya R, Chowdhury D, Borkar R, Srinivas R, Pal Bhadra M, Banerjee SK. Garlic attenuates cardiac oxidative stress via activation of PI3K/AKT/Nrf2Keap1 pathway in fructose-fed diabetic rat. PLoS One. 2014;9:e94228.

97. Götschel F, Kern C, Lang S, Sparna T, Markmann C, Schwager J, McNelly S, von Weizsäcker F, Laufer S, Hecht A, Merfort I. Inhibition of GSK3 differentially modulates NF-kB, CREB, AP-1 and $\beta$-catenin signaling in hepatocytes, but fails to promote TNFa-induced apoptosis. Exp Cell Res. 2008;314:1351-66.

98. Zhang ZF, Lu J, Zheng YL, Hu B, Fan SH, Wu DM, Zheng ZH, Shan Q, Liu CM. Purple sweet potato color protects mouse liver against d-galactoseinduced apoptosis via inhibiting caspase-3 activation and enhancing PI3K Akt pathway. Food Chem Toxicol. 2010;48:2500-7.

99. Cao Y, Ruan Y, Shen T, Huang X, Li M, Yu W, Zhu Y, Man Y, Wang S, Li J. Astragalus polysaccharide suppresses doxorubicin-induced cardiotoxicity by regulating the PI3k/Akt and p38MAPK pathways. Oxid Med Cell Longev. 2014;2014:674219

100. Zhu KX, Nie SP, Li C, Gong D, Xie MY. Ganoderma atrum polysaccharide improves aortic relaxation in diabetic rats via PI3K/Akt pathway. Carbohydr Polym. 2014;103:520-7.

101. Chen J, Jin X, Chen J, Liu C. Glycyrrhiza polysaccharide induces apoptosis and inhibits proliferation of human hepatocellular carcinoma cells by blocking PI3K/AKT signal pathway. Tumour Biol. 2013;34:1381-9.

102. Chen J, Yao D, Yuan H, Zhang S, Tian J, Guo W, Liang W, Li H, Zhang Y. Dipsacus asperoides polysaccharide induces apoptosis in osteosarcoma cells by modulating the PI3K Akt pathway. Carbohydr Polym. 2013;95:780-4.

103. Kwon MJ, Nam TJ. A polysaccharide of the marine alga Capsosiphon fulvescens induces apoptosis in AGS gastric cancer cells via an IGF-IRmediated PI3K/Akt pathway. Cell Biol Int. 2007;31:768-75.

104. Liu C, Li J, Meng FY, Liang SX, Deng R, Li CK, Pong NH, Lau CP, Cheng SW, Ye JY, Chen JL, Yang ST, Yan H, Chen S, Chong BH, Yang M. Polysaccharides from the root of Angelica sinensis promotes hematopoiesis and thrombopoiesis through the PI3K/AKT pathway. BMC Complement Altern Med. 2010;10:79.

105. Zhang Y, Hu T, Zhou H, Zhang Y, Jin G, Yang Y. Antidiabetic effect of polysaccharides from Pleurotus ostreatus in streptozotocin-induced diabetic rats. Int J Biol Macromol. 2016;83:126-32.

106. Ma X, Zhou F, Chen Y, Zhang Y, Hou L, Cao X, Wang C. A polysaccharide from Grifola frondosa relieves insulin resistance of HepG2 cell by Akt-GSK3 pathway. Glycoconj J. 2014;31:355-63.

107. Wang LY, Wang Y, Xu DS, Ruan KF, Feng Y, Wang S. MDG-1, a polysaccharide from Ophiopogon japonicus exerts hypoglycemic effects through the PI3K/Akt pathway in a diabetic KKAy mouse model. J Ethnopharmacol. 2012;143:347-54.

108. Sohara E, Rai T, Yang SS, Ohta A, Naito S, Chiga M, Nomura N, Lin SH, Vandewalle A, Ohta E, Sasaki S, Uchida S. Acute insulin stimulation induces phosphorylation of the $\mathrm{NaCl}$ cotransporter in cultured distal mpkDCT cells and mouse kidney. PLoS One. 2011;6:e24277.

109. Chiga M, Rai T, Yang SS, Ohta A, Takizawa T, Sasaki S, Uchida S. Dietary salt regulates the phosphorylation of OSR1/SPAK kinases and the sodium chloride cotransporter through aldosterone. Kidney Int. 2008;74: 1403-9. 
110. Takadera T, Ohtsuka M, Aoki H. Chelation of extracellular calcium-induced cell death was prevented by glycogen synthase kinase-3 inhibitors in PC12 cells. Cell Mol Neurobiol. 2010;30:193-8.

111. Su NY, Peng TC, Tsai PC, Huang CJ. Phosphoinositide 3-kinase/Akt pathway is involved in mediating the anti-inflammation effects of magnesium sulfate. J Surg Res. 2013;185:726-32.

112. Qiao D, Meyer K, Friedl A. Glypican 1 stimulates S phase entry and DNA replication in human glioma cells and normal astrocytes. Mol Cell Biol. 2013; 33:4408-21.

113. Chen Y, Scully M, Dawson G, Goodwin C, Xia M, Lu X, Kakkar A. Perturbation of the heparin/heparin-sulfate interactome of human breast cancer cells modulates pro-tumourigenic effects associated with PI3K/Akt and MAPK ERK signalling. Thromb Haemost. 2013;109:1148-57.

114. Goyal A, Poluzzi C, Willis CD, Smythies J, Shellard A, Neill T, lozzo RV Endorepellin affects angiogenesis by antagonizing diverse vascular endothelial growth factor receptor 2 (VEGFR2)-evoked signaling pathways: transcriptional repression of hypoxia-inducible factor $1 a$ and VEGFA and concurrent inhibition of nuclear factor of activated T cell 1 (NFAT1) activation. J Biol Chem. 2012;287:43543-56.

115. Brauer R, Ge L, Schlesinger SY, Birkland TP, Huang Y, Parimon T, Lee V, McKinney BL, McGuire JK, Parks WC, Chen P. Syndecan-1 attenuates lung injury during influenza infection by potentiating c-Met signaling to suppress epithelial apoptosis. Am J Respir Crit Care Med. 2016

116. Martín CP, Vázquez J, Avila J, Moreno FJ. P24, a glycogen synthase kinase 3 (GSK3) inhibitor. Biochim Biophys Acta. 2002;1586:113-22.

117. Ouyang P, Gottlieb SH, Culotta VL, Navas-Acien A. EDTA chelation therapy to reduce cardiovascular events in persons with diabetes. Curr Cardiol Rep. 2015;17:96.

118. Uranga RM, Giusto NM, Salvador GA. Iron-induced oxidative injury differentially regulates PI3K/Akt/GSK3 $\beta$ pathway in synaptic endings from adult and aged rats. Toxicol Sci. 2009;111:331-44.

119. Sarkar A, Sil PC. Iron oxide nanoparticles mediated cytotoxicity via PI3K/AKT pathway: role of quercetin. Food Chem Toxicol. 2014;71:106-15.

120. Ohashi K, Nagata Y, Wada E, Zammit PS, Shiozuka M, Matsuda R. Zinc promotes proliferation and activation of myogenic cells via the PI3K/Akt and ERK signaling cascade. Exp Cell Res. 2015;333:228-37.

121. Kim S, Jung Y, Kim D, Koh H, Chung J. Extracellular zinc activates p70 S6 kinase through the phosphatidylinositol 3-kinase signaling pathway. J Biol Chem. 2000;275:25979-84.

122. Walter PL, Kampkötter A, Eckers A, Barthel A, Schmoll D, Sies H, Klotz LO. Modulation of FoxO signaling in human hepatoma cells by exposure to copper or zinc ions. Arch Biochem Biophys. 2006;454:107-13.

123. Hickey JL, Crouch PJ, Mey S, Caragounis A, White JM, White AR, Donnelly PS. Copper(II) complexes of hybrid hydroxyquinoline-thiosemicarbazone ligands: GSK3 $\beta$ inhibition due to intracellular delivery of copper. Dalton Trans. 2011;40:1338-47.

124. Han CT, Schoene NW, Lei KY. Influence of zinc deficiency on Akt-Mdm2-p53 and Akt-p21 signaling axes in normal and malignant human prostate cells. Am J Physiol Cell Physiol. 2009;297:C1188-99.

125. Bae JH, Jang BC, Suh SI, Ha E, Baik HH, Kim SS, Lee MY, Shin DH. Manganese induces inducible nitric oxide synthase (iNOS) expression via activation of both MAP kinase and PI3K/Akt pathways in BV2 microglial cells. Neurosci Lett. 2006:398:151-4

126. Jang BC. Induction of COX-2 in human airway cells by manganese: role of PI3K/PKB, p38 MAPK, PKCs, Src, and glutathione depletion. Toxicol In Vitro. 2009;23:120-6.

127. Kanninen KM, Grubman A, Meyerowitz J, Duncan C, Tan JL, Parker SJ, Crouch PJ, Paterson BM, Hickey JL, Donnelly PS, Volitakis I, Tammen I, Palmer DN, White AR. Increased zinc and manganese in parallel with neurodegeneration, synaptic protein changes and activation of Akt/GSK3 signaling in ovine CLN6 neuronal ceroid lipofuscinosis. PLOS One. 2013;8:e58644.

128. Wu Y, Zu K, Warren MA, Wallace PK, Ip C. Delineating the mechanism by which selenium deactivates Akt in prostate cancer cells. Mol Cancer Ther. 2006:5:246-52

129. Ohsaka Y, Nishino H, Nomura Y. Adipose cells induce phospho-Thr-172 AMPK production by epinephrine or CL316243 in mouse 3T3-L1 adipocytes or MAPK activation and G protein-associated PI3K responses induced by CL316243 or aluminum fluoride in rat white adipocytes. Folia Biol (Praha). 2014;60:168-79.

130. Yu YN, Yang D, Zhu HZ, Deng CN, Guan ZZ. Expression of mRNA and protein of p38, Osx, PI3K and Akt1 in rat bone with chronic fluorosis. Zhonghua Bing Li Xue Za Zhi. 2012;41:622-6.
131. Hao C, Hao J, Wang W, Han Z, Li G, Zhang L, Zhao X, Yu G. Insulin sensitizing effects of oligomannuronate-Chromium (III) complexes in C2C12 skeletal muscle cells. PLoS One. 2011;6:e24598.

132. Katare RG, Caporali A, Oikawa A, Meloni M, Emanueli C, Madeddu P. Vitamin B1 analog benfotiamine prevents diabetes-induced diastolic dysfunction and heart failure through Akt/Pim-1-mediated survival pathway. Circ Heart Fail. 2010;3:294-305

133. Sun XJ, Zhao L, Zhao N, Pan XL, Fei GQ, Jin LR, Zhong CJ. Benfotiamine prevents increased $\beta$-amyloid production in HEK cells induced by high glucose. Neurosci Bull. 2012;28:561-6.

134. Pan X, Gong N, Zhao J, Yu Z, Gu F, Chen J, Sun X, Zhao L, Yu M, Xu Z, Dong W, Qin Y, Fei G, Zhong C, Xu TL. Powerful beneficial effects of benfotiamine on cognitive impairment and $\beta$-amyloid deposition in amyloid precursor protein/presenilin-1 transgenic mice. Brain. 2010;133:1342-51.

135. Sun H, Li G, Zhang W, Zhou Q, Yu Y, Shi Y, Offermanns S, Lu J, Zhou N. Niacin activates the PI3K/Akt cascade via PKC- and EGFR-transactivationdependent pathways through hydroxyl-carboxylic acid receptor 2. PLoS One. 2014;9:e112310.

136. Wu Y, Liu Y, Han Y, Cui B, Mi Q, Huang Y, Wang L, Jiang Q, Chen Q, Liu N, Ferro A, Ji Y. Pyridoxine increases nitric oxide biosynthesis in human platelets. Int J Vitam Nutr Res. 2009;79:95-103.

137. Han W, Gills JJ, Memmott RM, Lam S, Dennis PA. The chemopreventive agent myoinositol inhibits Akt and extracellular signal-regulated kinase in bronchial lesions from heavy smokers. Cancer Prev Res (Phila). 2009; 2:370-6.

138. Yu M, Li W, Luo S, Zhang Y, Liu H, Gao Y, Wang X, Wilson JX, Huang G. Folic acid stimulation of neural stem cell proliferation is associated with altered methylation profile of PI3K/Akt/CREB. J Nutr Biochem. 2014;25:496-502.

139. Yu WH, Ho YL, Huang PT, Chu SL, Tsai HJ, Liou HH. The phosphorylation state of GSK3 $\beta$ Serine 9 correlated to the development of valproic acidassociated fetal cardiac teratogenicity, fetal VPA syndrome, rescued by folic acid administration. Cardiovasc Toxicol. 2016;16:34-45.

140. Xu XM, Sansores-Garcia L, Chen XM, Matijevic-Aleksic N, Du M, Wu KK. Suppression of inducible cyclooxygenase 2 gene transcription by aspirin and sodium salicylate. Proc Natl Acad Sci U S A. 1999;96:5292-7.

141. Markworth JF, Cameron-Smith D. Prostaglandin F2\&alpha; stimulates PI3K ERK/mTOR signaling and skeletal myotube hypertrophy. Am J Physiol Cell Physiol. 2011;300:C671-82.

142. Mardini IA, FitzGerald GA. Selective inhibitors of cyclooxygenase-2: a growing class of anti-inflammatory drugs. Mol Interv. 2001;1:30-8.

143. Choi YJ, Yoon Y, Lee KY, Kang YP, Lim DK, Kwon SW, Kang KW, Lee SM, Lee $\mathrm{BH}$. Orotic acid induces hypertension associated with impaired endothelial nitric oxide synthesis. Toxicol Sci. 2015;144:307-17.

144. Norris ER, Majnarich JJ. Vitamin B14 and cell proliferation. Science. 1949;109: 32-3.

145. Makarević J, Rutz J, Juengel E, Kaulfuss S, Reiter M, Tsaur I, Bartsch G, Haferkamp A, Blaheta RA. Amygdalin blocks bladder cancer cell growth in vitro by diminishing cyclin A and cdk2. PLoS One. 2014;9:e105590.

146. Xu F, Yu H, Liu J, Cheng L. Pyrroloquinoline quinone inhibits oxygen/ glucose deprivation-induced apoptosis by activating the PI3K/AKT pathway in cardiomyocytes. Mol Cell Biochem. 2014:386:107-15.

147. Zhang Q, Ding M, Gao XR, Ding F. Pyrroloquinoline quinone rescues hippocampal neurons from glutamate-induced cell death through activation of Nrf2 and up-regulation of antioxidant genes. Genet Mol Res. 2012;11:2652-64.

148. Zhang Q, Ding M, Cao Z, Zhang J, Ding F, Ke K. Pyrroloquinoline quinine protects rat brain cortex against acute glutamate-induced neurotoxicity. Neurochem Res. 2013;38:1661-71.

149. Park JH, Kim JJ, Bae YS. Involvement of PI3K-AKT-mTOR pathway in protein kinase CKII inhibition-mediated senescence in human colon cancer cells. Biochem Biophys Res Commun. 2013:433:420-5

150. Guerriero E, Sorice A, Capone F, Napolitano V, Colonna G, Storti G, Castello G, Costantini S. Vitamin C effect on mitoxantrone-induced cytotoxicity in human breast cancer cell lines. PLoS One. 2014;9:e115287.

151. Hughes PJ, Lee JS, Reiner NE, Brown G. The vitamin D receptor-mediated activation of phosphatidylinositol 3-kinase (PI3Ka) plays a role in the 1a,25dihydroxyvitamin D3-stimulated increase in steroid sulphatase activity in myeloid leukaemic cell lines. J Cell Biochem. 2008;103:1551-72.

152. Zhang $X$, Zanello LP. Vitamin D receptor-dependent $1 a, 25(\mathrm{OH}) 2$ vitamin D3induced anti-apoptotic PI3K/AKT signaling in osteoblasts. J Bone Miner Res. 2008;23:1238-48. 
153. Borges CC, Salles AF, Bringhenti I, Souza-Mello V, Mandarim-de-Lacerda CA, Aguila MB. Adverse effects of vitamin D deficiency on the PI3K/Akt pathway and pancreatic islet morphology in diet-induced obese mice. Mol Nutr Food Res. 2016;60:346-57.

154. Axanova LS, Chen YQ, McCoy T, Sui G, Cramer SD. 1,25-dihydroxyvitamin $D(3)$ and PI3K/AKT inhibitors synergistically inhibit growth and induce senescence in prostate cancer cells. Prostate. 2010;70:1658-71.

155. Ferreira GB, Vanherwegen AS, Eelen G, Gutiérrez AC, Van Lommel L, Marchal K, Verlinden L, Verstuyf A, Nogueira T, Georgiadou M, Schuit F, Eizirik DL, Gysemans C, Carmeliet P, Overbergh L, Mathieu C. Vitamin D3 induces tolerance in human dendritic cells by activation of intracellular metabolic pathways. Cell Rep. 2015;10(5):711-25.

156. Datta-Mitra A, Mitra A, Ray R, Raychaudhuri SP, Kundu-Raychaudhuri S. 1,25Dihydroxyvitamin D3-3-bromoacetate, a novel vitamin D analog induces immunosuppression through PI3K/Akt/mTOR signaling cascade. Int Immunopharmacol. 2013;17:744-51.

157. Numakawa Y, Numakawa T, Matsumoto T, Yagasaki Y, Kumamaru E, Kunugi $H$, Taguchi T, Niki E. Vitamin E protected cultured cortical neurons from oxidative stress-induced cell death through the activation of mitogenactivated protein kinase and phosphatidylinositol 3-kinase. J Neurochem. 2006;97:1191-202.

158. Nakaso K, Tajima N, Horikoshi Y, Nakasone M, Hanaki T, Kamizaki K, Matsura $T$. The estrogen receptor $\beta$-PI3K/Akt pathway mediates the cytoprotective effects of tocotrienol in a cellular Parkinson's disease model. Biochim Biophys Acta. 1842;2014:1303-12.

159. Luo D, Or TC, Yang CL, Lau AS. Anti-inflammatory activity of iridoid and catechol derivatives from Eucommia ulmoides Oliver. ACS Chem Neurosci. 2014;5:855-66.

160. Hafizi S, Dahlbäck B. Gas6 and protein S. Vitamin K-dependent ligands for the Axl receptor tyrosine kinase subfamily. FEBS J. 2006;273(23):5231-44.

161. Tsai T, Klausmeyer A, Conrad R, Gottschling C, Leo M, Faissner A, Wiese S. 7,8Dihydroxyflavone leads to survival of cultured embryonic motoneurons by activating intracellular signaling pathways. Mol Cell Neurosci. 2013;56:18-28.

162. Urazaeva LG. Anti-inflammatory effect of methylmethionine sulfonium chloride (vitamin U). Farmakol Toksikol. 1976;39:316-9.

163. Song F, Zhu Y, Shi Z, Tian J, Deng X, Ren J, Andrews MC, Ni H, Ling W, Yang $Y$. Plant food anthocyanins inhibit platelet granule secretion in hypercholesterolaemia: Involving the signalling pathway of PI3K-Akt. Thromb Haemost. 2014;112:981-91.

164. Lu JN, Lee WS, Nagappan A, Chang SH, Choi YH, Kim HJ, Kim GS, Ryu CH, Shin SC, Jung JM, Hong SC. Anthocyanins from the fruit of Vitis coignetiae Pulliat potentiate the cisplatin activity by inhibiting PI3K/Akt signaling pathways in human gastric cancer cells. J Cancer Prev. 2015;20:50-6.

165. Afaq F, Zaman N, Khan N, Syed DN, Sarfaraz S, Zaid MA, Mukhtar H. Inhibition of epidermal growth factor receptor signaling pathway by delphinidin, an anthocyanidin in pigmented fruits and vegetables. Int J Cancer. 2008;123:1508-15.

166. Park SY, Lee YK, Lee WS, Park OJ, Kim YM. The involvement of AMPK/GSK3ß signals in the control of metastasis and proliferation in hepato-carcinoma cells treated with anthocyanins extracted from Korea wild berry Meoru. BMC Complement Altern Med. 2014;14:109.

167. Yan F, Zhang J, Zhang L, Zheng X. Mulberry anthocyanin extract regulates glucose metabolism by promotion of glycogen synthesis and reduction of gluconeogenesis in human HepG2 cells. Food Funct. 2016;7:425-33.

168. Zhu QW, Li YG. Berberine attenuates myocardial ischemia reperfusion injury by suppressing the activation of PI3KJAKT signaling. Expe Ther Medi. 2016;11:978-84.

169. Chai YS, Hu J, Lei F, Wang YG, Yuan ZY, Lu X, Wang XP, Du F, Zhang D, Xing DM, Xing DM, Du LJ. Effect of berberine on cell cycle arrest and cell survival during cerebral ischemia and reperfusion and correlations with p53/ cyclin D1 and PI3K/Akt. Eur J Pharmac. 2013;708:44-55.

170. Eo SH, Kim JH, Kim SJ. Induction of G2/M arrest by berberine via activation of PI3K Akt and p38 in human chondrosarcoma cell line. Oncol. 2015;22:147-57.

171. Qiao Q, Jiang Y, Li G. Inhibition of the PI3K AKT-NF-kB pathway with curcumin enhanced radiation-induced apoptosis in human Burkitt's lymphoma. J Pharmacol Sci. 2013;121:247-56.

172. Li XJ, Li YZ, Jin CT, Fan J, Li HJ. Curcumin induces apoptosis by PTEN/PI3K/AKT pathway in EC109 cells. Zhongguo Ying Yong Sheng Li Xue Za Zhi. 2015;31:174-7.

173. Seo BR, Min KJ, Cho IJ, Kim SC, Kwon TK. Curcumin significantly enhances dual PI3KJAkt and mTOR inhibitor NVP-BEZ235-induced apoptosis in human renal carcinoma Caki cells through down-regulation of p53-dependent Bcl-2 expression and inhibition of Mcl-1 protein stability. PLoS One. 2014;9:e95588.
174. Yu W, Zha W, Ke Z, Min Q, Li C, Sun H, Liu C. Curcumin protects neonatal rat cardiomyocytes against high glucose-induced apoptosis via PI3K/Akt signalling pathway. J Diab Res. 2016;ID 4158591.

175. Yu S, Shen G, Khor TO, Kim JH, Kong AN. Curcumin inhibits Akt/mammalian target of rapamycin signaling through protein phosphatase-dependent mechanism. Mol Cancer Ther. 2008;7:2609-20.

176. Bustanji Y, Taha MO, Almasri IM, Al-Ghussein MA, Mohammad MK, Alkhatib HS. Inhibition of glycogen synthase kinase by curcumin: Investigation by simulated molecular docking and subsequent in vitro/in vivo evaluation. J Enzyme Inhib Med Chem. 2009;24:771-8.

177. Ang L, Yuguang L, Liying W, Shuying Z, Liting X, Shumin W. Ergosterol alleviates kidney injury in streptozotocin-induced diabetic mice. Evid Based Complement Alternat Med. 2015;2015:691594.

178. Kunoh T, Noda T, Koseki K, Sekigawa M, Takagi M, Shin-ya K, Goshima N, lemura S, Natsume T, Wada S, Mukai Y, Ohta S, Sasaki R, Mizukami T. A novel human dynactin-associated protein, dynAP, promotes activation of Akt, and ergosterol-related compounds induce dynAP-dependent apoptosis of human cancer cells. Mol Cancer Ther. 2010;9:2934-42.

179. Xie K, Nian J, Zhu X, Geng X, Liu F. Modulatory role of garlicin in migration and invasion of intrahepatic cholangiocarcinoma via PI3K/AKT pathway. Int J Clin Exp Pathol. 2015;8:14028-33.

180. Bagli E, Stefaniotou M, Morbidelli L, Ziche M, Psillas K, Murphy C, Fotsis T. Luteolin inhibits vascular endothelial growth factor-induced angiogenesis; inhibition of endothelial cell survival and proliferation by targeting phosphatidylinositol 3'-kinase activity. Cancer Res. 2004;64:7936-46.

181. Fang J, Zhou Q, Shi XL, Jiang BH. Luteolin inhibits insulin-like growth factor 1 receptor signaling in prostate cancer cells. Carcinogenesis. 2007;28:713-23.

182. Lim do Y, Cho HJ, Kim J, Nho CW, Lee KW, Park JH. Luteolin decreases IGF-II production and downregulates insulin-like growth factor-I receptor signaling in HT-29 human colon cancer cells. BMC Gastroenterol. 2012;12:9.

183. Cheng WY, Chiao MT, Liang YJ, Yang YC, Shen CC, Yang CY. Luteolin inhibits migration of human glioblastoma U-87 MG and T98G cells through downregulation of Cdc42 expression and PI3K/AKT activity. Mol Biol Rep. 2013;40:5315-26.

184. Fang F, Li D, Pan H, Chen D, Qi L, Zhang R, Sun H. Luteolin inhibits apoptosis and improves cardiomyocyte contractile function through the PI3K/Akt pathway in simulated ischemia/reperfusion. Pharmacology. 2011; 88:149-58.

185. El Omri A, Han J, Kawada K, Ben Abdrabbah M, Isoda H. Luteolin enhances cholinergic activities in PC12 cells through ERK1/2 and PI3K/Akt pathways. Brain Res. 2012;1437:16-25

186. Chen J, O'Donoghue A, Deng YF, Zhang B, Kent F, O'Hare T. The effect of lycopene on the PI3K/Akt signalling pathway in prostate cancer. Anticancer Agents Med Chem. 2014;14:800-5.

187. Bhukhai K, Suksen K, Bhummaphan N, Janjorn K, Thongon N, Tantikanlayaporn D, Piyachaturawat P, Suksamrarn A, Chairoungdua A. A phytoestrogen diarylheptanoid mediates estrogen receptor/Akt/glycogen synthase kinase $3 \beta$ protein-dependent activation of the Wnt/ $\beta$-catenin signaling pathway. J Biol Chem. 2012;287:36168-78.

188. Ahmad A, Biersack B, Li Y, Kong D, Bao B, Schobert R, Padhye SB, Sarkar FH. Deregulation of PI3K/Akt/mTOR signaling pathways by isoflavones and its implication in cancer treatment. Anticancer Agents Med Chem. 2013;13:1014-24.

189. Tang $Y$, Li S, Zhang P, Zhu J, Meng G, Xie L, Yu Y, Ji Y, Han Y. Soy isoflavone protects myocardial ischemia/reperfusion injury through increasing endothelial nitric oxide synthase and decreasing oxidative stress in ovariectomized rat. Oxid Med Cell Longev. 2016;2016:Article ID 5057405.

190. Martínez-Montemayor MM, Otero-Franqui E, Martinez J, De La MotaPeynado A, Cubano LA, Dharmawardhane S. Individual and combined soy isoflavones exert differential effects on metastatic cancer progression. Clin Exp Metastasis. 2010;27:465-80.

191. Yang HJ, Youn H, Seong KM, Yun YJ, Kim W, Kim YH, Lee JY, Kim CS, Jin YW Youn B. Psoralidin, a dual inhibitor of COX-2 and 5-LOX, regulates ionizing radiation (IR)-induced pulmonary inflammation. Biochem Pharmacol. 2011 82:524-34.

192. Jiang H, Shang X, Wu H, Gautam SC, Al-Holou S, Li C, Kuo J, Zhang L, Chopp M. Resveratrol downregulates PI3K/Akt/mTOR signaling pathways in human U251 glioma cells. J Exp Ther Oncol. 2009;8:25-33.

193. Liu MH, Yuan C, He J, Tan TP, Wu SJ, Fu HY, Liu J, Yu S, Chen YD, Le QF, Tian W, Hu HJ, Zhang Y, Lin XL. Resveratrol protects PC12 cells from high glucose-induced neurotoxicity via PI3K/Akt/FoxO3a pathway. Cell Mol Neurobiol. 2015;35:513-22 
194. Varamini B, Sikalidis AK, Bradford KL. Resveratrol increases cerebral glycogen synthase kinase phosphorylation as well as protein levels of drebrin and transthyretin in mice: an exploratory study. Int J Food Sci Nutr. 2014;65:89-96.

195. Peuhu E, Rivero-Müller A, Stykki H, Torvaldson E, Holmbom T, Eklund P, Unkila M, Sjöholm R, Eriksson JE. Inhibition of Akt signaling by the lignin matairesinol sensitizes prostate cancer cells to TRAIL-induced apoptosis. Oncogene. 2010;29:898-908.

196. Kim BH, Cho JY. Anti-inflammatory effect of honokiol is mediated by PI3K Akt pathway suppression. Acta Pharmacol Sin. 2008;29:113-22.

197. Crane C, Panner A, Pieper RO, Arbiser J, Parsa AT. Honokiol-mediated inhibition of PI3K/mTOR pathway: a potential strategy to overcome immunoresistance in glioma, breast, and prostate carcinoma without impacting T cell function. J Immunother. 2009;32:585-92.

198. Kay HY, Kim YW, da Ryu H, Sung SH, Hwang SJ, Kim SG. Nrf2-mediated liver protection by sauchinone, an antioxidant lignan, from acetaminophen toxicity through the PKCS-GSK3ß pathway. Br J Pharmacol. 2011;163:1653-65.

199. Chen Y, Willcockson HH, Valtschanoff JG. Influence of the vanilloid receptor TRPV1 on the activation of spinal cord glia in mouse models of pain. Exp Neurol. 2009;220:383-90

200. Malagarie-Cazenave S, Olea-Herrero N, Vara D, Díaz-Laviada I. Capsaicin, a component of red peppers, induces expression of androgen receptor via PI3K and MAPK pathways in prostate LNCaP cells. FEBS Lett. 2009:583:141-7.

201. Gao YJ, Ji RR. c-Fos and pERK, which is a better marker for neuronal activation and central sensitization after noxious stimulation and tissue injury? Open Pain J. 2009;2:11-7.

202. Kim SR, Kim SU, Oh U, Jin BK. Transient receptor potential vanilloid subtype 1 mediates microglial cell death in vivo and in vitro via $\mathrm{Ca}^{2+}$-mediated mitochondrial damage and cytochrome c release. J Immunol. 2006;177:4322-9.

203. Lee SH, Krisanapun C, Baek SJ. NSAID-activated gene-1 as a molecular target for capsaicin-induced apoptosis through a novel molecular mechanism involving GSK3 $\beta$, C/EBP $\beta$ and ATF3. Carcinogenesis. 2010;31:719-28.

204. Bonsi P, Cuomo D, De Persis C, Centonze D, Bernardi G, Calabresi P, Pisani A. Modulatory action of metabotropic glutamate receptor (mGluR) 5 on mGluR1 function in striatal cholinergic interneurons. Neuropharmacology. 2005;49 Suppl 1:104-13.

205. Maragakis NJ, Rothstein JD. Glutamate transporters in neurologic disease. Arch Neurol. 2001:58:365-70.

206. Shah SA, Lee HY, Bressan RA, Yun DJ, Kim MO. Novel osmotin attenuates glutamate-induced synaptic dysfunction and neurodegeneration via the JNK/PI3KJAkt pathway in postnatal rat brain. Cell Death Dis. 2014;5:e1026.

207. Nehlig A, Daval JL, Debry G. Caffeine and the central nervous system: mechanisms of action, biochemical, metabolic and psychostimulanteffects. Brain Res Brain Res Rev. 1992;17:139-70.

208. Ribeiro JA, Sebastião AM. Caffeine and adenosine. J Alzheimers Dis. 2010;20 Suppl 1:S3-15

209. Fredholm BB, IJzerman AP, Jacobson KA, Klotz KN, Linden J. International Union of Pharmacology. XXV. Nomenclature and classification of adenosine receptors. Pharmacol Rev. 2001;53:527-52.

210. Nakaso K, Ito S, Nakashima K. Caffeine activates the PI3K/Akt pathway and prevents apoptotic cell death in a Parkinson's disease model of SH-SY5Y cells. Neurosci Lett. 2008;432:146-50.

211. Saiki S, Sasazawa Y, Imamichi Y, Kawajiri S, Fujimaki T, Tanida I, Kobayashi H, Sato F, Sato S, Ishikawa K, Imoto M, Hattori N. Caffeine induces apoptosis by enhancement of autophagy via PI3K/Akt/mTOR/p70S6K inhibition. Autophagy. 2011;7:176-87.

212. Kim AR, Yoon BK, Park H, Seok JW, Choi H, Yu JH, Choi Y, Song SJ, Kim A, Kim JW. Caffeine inhibits adipogenesis through modulation of mitotic clonal expansion and the AKT/GSK3 pathway in 3T3-L1 adipocytes. BMB Rep. 2016;49:111-5.

213. Pohler H. Caffeine intoxication and addiction. J Nurse for Practitioners. 2010; 6:49-52.

214. Zeng T, Zhang CL, Song FY, Zhao XL, Yu LH, Zhu ZP, Xie KQ. PI3K/Akt pathway activation was involved in acute ethanol-induced fatty liver in mice. Toxicology. 2012;296:56-66.

215. Neznanova O, Björk K, Rimondini R, Hansson AC, Hyytiä P, Heilig M, Sommer WH. Acute ethanol challenge inhibits glycogen synthase kinase-3 $\beta$ in the rat prefrontal cortex. Int J Neuropsychopharmacol. 2009;12:275-80.

216. Liu J, Tian Z, Gao B, Kunos G. Dose-dependent activation of antiapoptotic and proapoptotic pathways by ethanol treatment in human vascular endothelial cells: differential involvement of adenosine. J Biol Chem. 2002; 277:20927-33
217. Hur MW, Edenberg HJ. Cloning and characterization of the ADH5 gene encoding human alcohol dehydrogenase 5, formaldehyde dehydrogenase. Gene. 1992;121:305-11.

218. Ma H, Yu L, Byra EA, Hu N, Kitagawa K, Nakayama Kl, Kawamoto T, Ren J. Aldehyde dehydrogenase 2 knockout accentuates ethanol-induced cardiac depression: role of protein phosphatases. J Mol Cell Cardiol. 2010;49:322-9.

219. Svegliati-Baroni G, Ridolfi F, Di Sario A, Saccomanno S, Bendia E, Benedetti A, Greenwel P. Intracellular signaling pathways involved in acetaldehydeinduced collagen and fibronectin gene expression inhuman hepatic stellate cells. Hepatology. 2001;33:1130-40.

220. Svegliati-Baroni G, Inagaki Y, Rincon-Sanchez AR, Else C, Saccomanno S, Benedetti A, Ramirez F, Rojkind M. Early response of alpha2(I) collagen to acetaldehyde in human hepatic stellate cells is TGF- $\beta$ independent. Hepatology. 2005:42:343-52.

221. Apte M, McCarroll J, Pirola R, Wilson J. Pancreatic MAP kinase pathways and acetaldehyde. Novartis Found Symp. 2007;285:200-11. discussion 211-6.

222. Higdon JV, Frei B. Tea catechins and polyphenols: health effects, metabolism, and antioxidant functions. Crit Rev Food Sci Nutr. 2003:43:89-143.

223. Nomura M, Kaji A, He Z, Ma WY, Miyamoto K, Yang CS, Dong Z. Inhibitory mechanisms of tea polyphenols on the ultraviolet B-activated phosphatidylinositol 3-kinase-dependent pathway. J Biol Chem. 2001;276:46624-31.

224. Park G, Yoon BS, Moon JH, Kim B, Jun EK, Oh S, Kim H, Song HJ, Noh JY, Oh C, You S. Green tea polyphenol epigallocatechin-3-gallate suppresses collagen production and proliferation in keloid fibroblasts via inhibition of the STAT3-signaling pathway. J Invest Dermatol. 2008;128:2429-41.

225. Johnson JJ, Bailey HH, Mukhtar H. Green tea polyphenols for prostate cancer chemoprevention: a translational perspective. Phytomedicine. 2010;17:3-13.

226. Shirakami Y, Shimizu M, Adachi S, Sakai H, Nakagawa T, Yasuda Y, Tsurumi $\mathrm{H}$, Hara $Y$, Moriwaki H. (-)-Epigallocatechin gallate suppresses the growth of human hepatocellular carcinoma cells by inhibiting activation of the vascular endothelial growth factor-vascular endothelial growth factor receptor axis. Cancer Sci. 2009;100:1957-62.

227. Liu S, Wang XJ, Liu Y, Cui YF. PI3K/AKT/mTOR signaling is involved in (-)-epigallocatechin-3-gallate-induced apoptosis of human pancreatic carcinoma cells. Am J Chin Med. 2013;41:629-42.

228. Kim MJ, Kim HI, Chung J, Jeong TS, Park HR. (-)-Epigallocatechin-3-gallate (EGCG) increases the viability of serum-starved A549 cells through its effect on Akt. Am J Chin Med. 2009;37:723-34.

229. Lin CL, Chen TF, Chiu MJ, Way TD, Lin JK. Epigallocatechin gallate (EGCG) suppresses $\beta$-amyloid-induced neurotoxicity through inhibiting c-Abl/FE65 nuclear translocation and GSK3 $\beta$ activation. Neurobiol Aging. 2009;30:81-92.

\section{Submit your next manuscript to BioMed Central and we will help you at every step:}

- We accept pre-submission inquiries

- Our selector tool helps you to find the most relevant journal

- We provide round the clock customer support

- Convenient online submission

- Thorough peer review

- Inclusion in PubMed and all major indexing services

- Maximum visibility for your research

Submit your manuscript at www.biomedcentral.com/submit 